Fall 2020

\title{
Research Across the Curriculum: Using Cognitive Science to Answer the Call for Better Legal Research Instruction
}

Tenielle Fordyce-Ruff

Concordia University School of Law

Follow this and additional works at: https://ideas.dickinsonlaw.psu.edu/dlr

Part of the Adult and Continuing Education Commons, Cognitive Psychology Commons, Curriculum and Instruction Commons, Curriculum and Social Inquiry Commons, Educational Assessment, Evaluation, and Research Commons, Educational Leadership Commons, Educational Methods Commons, Educational Psychology Commons, Law and Psychology Commons, Law and Society Commons, Legal Profession Commons, Legal Studies Commons, Legal Writing and Research Commons, and the Other Social and Behavioral Sciences Commons

\section{Recommended Citation}

Tenielle Fordyce-Ruff, Research Across the Curriculum: Using Cognitive Science to Answer the Call for Better Legal Research Instruction, 125 DICK. L. REV. 1 (2020).

Available at: https://ideas.dickinsonlaw.psu.edu/dlr/vol125/iss1/2

This Article is brought to you for free and open access by the Law Reviews at Dickinson Law IDEAS. It has been accepted for inclusion in Dickinson Law Review by an authorized editor of Dickinson Law IDEAS. For more information, please contact lja10@psu.edu. 


\section{Articles}

\section{Research Across the Curriculum: Using Cognitive Science to Answer the Call for Better Legal Research Instruction}

\section{Tenielle Fordyce-Ruff*}

\section{Abstract}

The American Bar Association (ABA), law students, and employers are demanding that law schools do better when teaching legal research. Academic critics are demanding that law professors begin to apply the lessons from the science of learning to improve student outcomes. The practice of law is changing.

Yet, the data shows that law schools are not changing their legal research curriculum to respond to the need of their students or to address the ABA's mandate. This stagnation comes at the same time as an explosion in legal information and a decrease in technical research skills among incoming students. This article explores the tension law schools face in changing their curriculum, how schools will need to respond as they begin to assess legal research competencies, and the best ways for them to respond to the changes in the legal research landscape. Impor-

\footnotetext{
* Associate Professor of Law and Director at The Legal Research and Writing Program, Concordia University School of Law. The author would like to thank Brenda Bauges, Jason Dykstra, and Jodi Nafzger for their generous support, helpful conversations, and all-around good natures. This article would not be possible without the help of my research assistants: Abigail Schwartz, Brit Kreimeyer, and Gwen Thomson.
} 
tantly, as the landscape changes, law schools can easily apply the lessons from cognitive psychology to improve their students' legal research skills.

Simply, students learn and retain best when they have spaced, varied, and interleaved practice with skills and knowledge. Thus, adding research discussion, lessons, or activities to courses across the curriculum would have little cost in terms of finances, minimal costs in terms of faculty time, and would not necessitate jettisoning doctrinal content from any course. Instead, this straightforward change in the delivery method of content would lead to better outcomes for students in both doctrinal knowledge and research skills. The time for changing the edges of law school curriculums or to adding more mandatory or even optional courses is past. Law schools can apply the lessons from cognitive psychology to produce better learning and transfer.

\section{TABle of Contents}

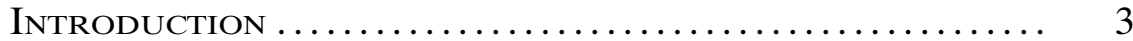

I. On Repeat-Calls for Better Skills

InSTRUCTION.................................

A. Call for a Change in Legal Education Generally: The First 120 Years .......................... 5

B. Call for a Change in Legal Education Heats Up: 1992-2007...............................

C. Call for a Change in Legal Education Since 2007: We Haven't Changed Enough...................

D. Call for Change from Outside the Academy: Recent Graduates and Their Employers Decry the State of Legal Education ...................... 13

II. The Need For Better Research Instruction.... 15

A. Faulty Assumptions Underlie the Curricular Decisions Regarding Legal Research .............

B. Law Students and Employers are Dissatisfied with Graduates' Legal Research Skills.................

C. The Landscape of Legal Research is Rapidly Changing ................................ 19

D. The Call for Research Across the Curriculum ..... 21

E. Challenges to Changing Legal Research Instruction .................................

III. The Legal Research Skills a Competent Novice Attorney Needs to Have..............

IV. The Current Placement of Legal Research InSTRUCTION . . . . . . . . . . . . . . . . . . . . . . . 
A. Legal Research Instruction Receives One CreditHour in the First Year .......................

B. Despite This Stagnation, Legal Research is More Complex, and Students are Less Academically Prepared .................................

V. What Cognitive Psychology Teaches Us About LEARning .................................

VI. Including Legal Research Across the Curriculum Would Create Competent Legal RESEARCHERS ............................... 42

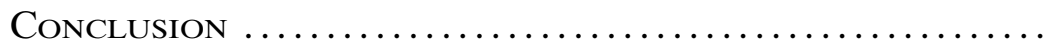

\section{INTRODUCTION}

The calls for reform in legal education are hardly new. ${ }^{1}$ Our model of legal education-based on the case method, Socratic teaching, and a common law curriculum-was obsolete by the time it became widespread. ${ }^{2}$ This model of legal education was

seriously out-of-date by the time of [its] triumph. [It] no longer comported with the practice of law or the theories of law, society and education. To rely on the Langdellian approach by 1914 was educationally irresponsible, a failure to keep pace with current events and current thinking; it was not even true to the spirit of the Langdell's own innovations, which had been entirely au courant when they were devised in the 1870s. ${ }^{3}$

While the curriculum at law schools has changed around the edges-with an increase in clinics, advanced legal writing, and professional development courses added-the basics of the first-year curriculum focused on common law followed by electives in the

1. See Marie Summerlin Hamm et al., The Rubric Meets the Road in Law Schools: Program Assessment of Student Learning Outcomes as a Fundamental Way for Law Schools to Improve and Fulfill Their Respective Missions, 95 U. DET. Mercy L. Rev. 343, 357 (2018); William G. Hammond et al., Report on the Committee of Legal Education, 13 Am. B. Ass'n Rep. 330 (1890); Albert J. Harno, Legal Education in the United States 137 (1953) (noting that the criticisms of legal education "all can be grouped under one heading, that the schools do not adequately prepare students for the tasks they will have to perform in the practice.”); ABA Section of Legal Educ. \& Admissions to the Bar, Report and Recommendations of the Task Force on Lawyer Competency: The Role OF LAW Schools, ABA Section of Legal Education and Admissions to the Bar 3-5 (1979); William M. Sullivan et al., Educating Lawyers for the ProFESSION OF LAW 8 (2007) [hereinafter Carnegie Foundation Report].

2. See Edward Rubin, What's Wrong with Langdell's Method and What to Do About It, 60 VAND. L. Rev. 609, 611-13 (2007).

3. Id. at 613 . 
next years remains relatively constant. ${ }^{4}$ This constancy in curriculum remains in spite of repeated calls for major curricular reform.

While the calls for curricular changes to law schools began as a tug-of-war between the proper balance of doctrinal teaching and skills instruction, the legal academy can no longer ignore the importance of skills instruction, particularly the importance of instruction in legal research. In 2014, the American Bar Association (ABA) began to require that law schools establish learning outcomes that include competency in legal research. ${ }^{5}$ Moreover, recent law school graduates and their employers are increasingly critical of new graduates' legal research skills. ${ }^{6}$

And the ABA's mandate to ensure competency in legal research comes at a time when access to legal information has exploded. Gone are the days of legal research being the exclusive domain of books and indexes, or even the days of legal research being the exclusive domain of books, Lexis, and Westlaw. ${ }^{7}$ Yet, the place of legal research instruction in the curriculum has remained stagnant; the academy has yet to change the standard curriculum to respond to the need for graduates to have competent legal research skills. $^{8}$

This article explores why and how law schools can use principles from cognitive psychology to respond to the need for graduates to have competency in legal research skills by adopting legal research across the curriculum. This article first explores the history of the tension between increasing skills instruction and doctrinal teaching, the academy's response to criticisms about the lack of skills instruction, and how this response has led to an undervaluing of skills instruction within the academy and by law students. It then turns to calls for better research instruction, specifically the call for including legal research across the curriculum and the challenges to implementing such a curricular change. Next, it examines the competencies a legal researcher needs to possess and the current placement and state of legal research instruction in the academy and

4. Catherine L. Carpenter, A Survey of Law School Curriculum 2002-2010 15 (2012); see also Rebecca Flanagan, Better by Design: Implementing Meaningful Change for the Next Generation of Law Students, 71 ME. L. REv. 103, 112 (2018) (noting that while law school has evolved since Langdell's introduction of the Socratic Method at Harvard Law School, legal education has not embraced the wholesale evaluation and design thinking necessary for legal education to meet the needs of novice learners and emerging professionals). 1996).

5. Standards \& Rules of Procedure Standard 302(b) (Am. Bar Ass'N

6. See infra notes $61-73$.

7. See infra notes $99-113$.

8. See infra notes 9-60. 
reviews the changes in legal research resources. It then examines cognitive science and psychology to examine how students learn best. Finally, it argues that including research across the curriculum would allow students to achieve the needed competency in legal research without placing undue burdens on law faculties.

\section{On Repeat-Calls for Better Skills Instruction}

The history of legal education has in many ways been a history of the academy's response to criticisms that led to the tension between increasing skills instruction and doctrinal courses. While the academy's response has led to some changes, it has also led to an undervaluing of skills instruction within the academy and by law students.

\section{A. Call for a Change in Legal Education Generally: The First 120 Years}

Ironically, perhaps, the first law schools opened in response to criticism of the apprentice method of legal education. ${ }^{9}$ Sir William Blackstone leveled criticism at the apprenticeship model of legal education. ${ }^{10}$ Blackstone noted that the apprenticeship model meant that attorneys who lacked training in the law as a whole would be "distract[ed] and bewilder[ed]" when presented with variations from what he learned through his apprenticeship. ${ }^{11}$

In response, a few universities established law departments and proprietary law schools proliferated. ${ }^{12}$ But the early law schools

9. Hamm et al., supra note 1, at 352 (noting that the first law schools opened in response to the criticisms leveled at the apprentice model of legal education).

10. Id. at 352. The apprentice method of legal education studied law with a practicing attorney. Jeffrey D. Jackson \& David R. Cleveland, Legal Writing: A History from the Colonial Era to the End of the Civil War, 19 LEgAL Writing: J. Legal Writing Inst. 191, 196-200 (2014). The apprentice would read the law, copy documents the attorney produced, and learn to practice law by practicing beside the attorney. Id. at 199-200 ("The apprentice system, with all of its inconsistencies, would continue to be the dominant manner of legal education for American lawyers from colonial times until the early nineteenth century. Some conscientious practitioners would endeavor to thoroughly educate their students in both the theory and practice of law, including 'conveyancing, pleading, copying, and other writing.' Others would find that outside duties, including service in Congress, made them too busy to properly attend to apprentices. By as early as the 1780 s, some progress was being made to teach both practical skills and the theory behind them, including writing, in what became the first 'private law schools.'"); see also Arthur D. Austin, Is the Casebook Method Obsolete?, 6 WM. \& MARY L. REV. 157, 158 (1965) (describing the office apprenticeship system of "reading law" which "remained the basic avenue into the legal profession until 1850").

11. Hamm et al., supra note 1 , at 352 .

12. Austin, supra note 10, at 159-61 (discussing the series of reforms that led from the apprenticeship system to the lecture system following the Civil War with 
did not shy away from skills education. ${ }^{13}$ Instead, prior to the advent of the Langdellian case method, classes in law schools blended skills instruction and hands-on instruction with lecture, all taught by practicing lawyers. ${ }^{14}$ Indeed, early law school curricula "sought to balance intellectual rigor and the necessity of being "practiceready.'" 15

The criticism of American legal education, however, continued. In 1890, the ABA noted defects in the method of instruction by law schools because students received no empiric training. But the $\mathrm{ABA}$ found it fortunate that the training law students did not gain in law school was "supplied in the early years of practice, at least to a very considerable extent." 16

Of course, economics took hold, with institutions seeing the benefits of the scalability of lectures, and casebooks became available. ${ }^{17}$ Soon, Dean Christopher Columbus Langdell developed the casebook method, designed around the idea that the law was a science and could be taught by those who had experience in learning the law. ${ }^{18}$ The ABA noticed: it formed its first ever section ${ }^{19}$ and reported that "[t]here is little if any dispute now as to the relative merit of education by means of law schools, and that to be got by mere practical training or apprenticeship as an attorney's clerk."20

While Langdell's method of legal education remains essentially unchanged in law schools, ${ }^{21}$ the response to his method has not

"[t]he increased complexity of the law ... the emergence of even more law schools"); Hamm et al., supra note 1, at 352-53; see generally Jackson \& Cleveland, supra note 10 .

13. See generally Jackson \& Cleveland, supra note 10 (discussing how the skills taught in modern legal research and writing courses were included in legal education from the colonial era until the Civil War).

14. Hamm et al., supra note 1, at 352-53. Moreover, the early years of Langdell's tenure at Harvard saw an increase in skills training. Jeffrey Jackson \& David Cleveland, Legal Writing: A History from the End of the Civil War to 1930, 24 Legal Writing: J. Legal Writing Inst. 87 (2020).

15. Hamm et al, supra note 1 , at 353.

16. Hammond, supra note 1, at 330.

17. Hamm et al., supra note 1 , at 354 .

18. Id.; Rubin, supra note 2, at 632-33 ("Since Langdell saw this methodology as a means of discerning general, objectively identifiable principles of law, he really seemed to believe that his approach was natural science itself."); Austin, supra note 10, at 162 (noting the scientific approach of Langdell's casebook method that tried "to apply the inductive method of the laboratory to matters foreign to the natural sciences.").

19. Hamm et al., supra note 1 , at 355 .

20. Am. Bar Ass'n, 1878 Report of the Second Annual Meeting 13 (1879); ABA Comm. On Juris. \& L. Reform 216 (1879).

21. Rubin, supra note 2, at 610; Jeremiah A. Ho, Function, Form, and Strawberries: Subverting Langdell, 64 J. LEg. Educ. 656, 660 (2015) (noting that 
been all positive. Nearly 60 years after extolling the virtues of the case method compared to the apprenticeship model, the ABA noted that all criticism of American legal education "can be grouped broadly under one heading; namely, that [the schools] do not adequately prepare students for the tasks they will perform in practice." 22

Nonetheless, by then the case method, Socratic teaching, and a common law curriculum had become the norm in the academy, even as skills instruction crept back in. ${ }^{23}$ Law schools began to add to their curriculum in an ad hoc manner, including adding skills instruction; clinics; jurisprudential, interdisciplinary, and comparative perspectives; and emerging fields of law and pedagogical methods. ${ }^{24}$ The addition of clinics and skills instruction was done, however, through the creation of a bifurcated faculty model. ${ }^{25}$

This model divided faculty into two "isolated and cloistered" units: doctrinal faculty who "concern[ed] themselves with scholarship and with guiding students to a theoretical understanding of the underpinnings of law[ ]" and skills faculty, who had more pragmatic

"the opportunity to reshape [Langdell's] model of legal education is now overdue").

22. Harno, supra note 1 , at 120.

23. "The case-dialogue method was considered an "abomination" by many of Langdell's contemporaries." See Harvard Law Sch., Centennial History of the Harvard LaW School 1817-1917 35 (1918) (quoted in Lawrence M. Friedman, A History of American Law 533 (1973)). See also Paul F. Teich, Research on American Law Teaching: Is There a Case Against the Case System?, 36 J. Leg. Educ. 167, 169-70 (1986) (noting that "initial reaction to the introduction of the case method was negative, extreme, and immediate"). Many advocated for a system of legal education that balanced theory and practice. The ABA Standing Committee's 1891 statement on "The Best Method for Teaching Law" declared that " $\mathrm{t}$ ]he student cannot practice by simply listening to a teacher expound principles of practice, but opportunity must be afforded him for doing himself the things which he will have to do in case of actual litigation. To this end practice courts should be established in all schools of law." Hamm et al., supra note 1, at 354 n.66. Likewise, in 1883 John Shirley opined "[t]here is no place for acquiring a mastery of general principles with apt illustrations like a thoroughly equipped law school. There is no place where a knowledge of man and things and the use of law can be so mastered as in a law office." John M. Shirley, The Future of Our ProfesSion: A Paper Read Before the American Bar 11 (1883). The debate has continued unabated for well over a century even as the Socratic case-dialogue remains firmly ensconced in legal education pedagogy." Hamm et al., supra note 1, at 354 .

24. Wallace Loh, Introduction: The MacCrate Report-Heuristic or Prescriptive?, 69 WAsh. L. Rev. 505, 506 (1994); Hamm et al., supra note 1, at 357; Genevieve Blake Tung, Academic Law Libraries and the Crisis in Legal Education, 105 L. LiB. J. 275, 282 (2013) ("Legal writing courses were added at some law schools by the mid-twentieth century. Clinical legal training was introduced in the 1960s and expanded quickly.").

25. Hamm et al, supra note 1, at 357; Tung, supra note 24, at 282. 
concerns and taught an impressive and vast array of skills. ${ }^{26}$ This bifurcated faculty model unfortunately siloed and marginalized skills instruction ${ }^{27}$ and allowed law schools to devote fewer resources to teaching students how to practice than to learning the science of the law through the Socratic method. ${ }^{28}$ In fact, many law schools answered the call for increased skills instruction by using adjunct faculty for specialty courses, and different faculty classifications proliferated for the faculty tasked with teaching skills. ${ }^{29}$

The bifurcated model contributed to students perceiving the value of skills based on the instructor and the number of credit hours. ${ }^{30}$ This perception did not lead students to value learning the skills necessary to practice law successfully. ${ }^{31}$ Perhaps this undervaluation of skills by faculty and students is the reason calls for reform to legal education have increased in volume over the last thirty years. ${ }^{32}$

26. Hamm et al., supra note 1 , at 357.

27. Ho, supra note 21, at 664 ("The current incarnation of the case method marginalizes skills most vividly through the way doctrinal courses stack knowledge over skills instruction. For instance, instead of a possibly more egalitarian approach among courses, the first-year curriculum will likely have four or five doctrinal courses-with each course ranging in credits worth three to six unitsjuxtaposed against one introductory course on legal research and writing that is most often capped at two units worth of credits.").

28. Mary Lu Bilek et al., ABA Section on Legal Educ. \& Admissions to the Bar, Twenty Years After the MacCrate Report: A Review of the Current State of the Legal Education Continuum and the Challenges FACING THE ACADEMY, BAR, AND Judiciary 11 (2013), https://bit.ly/31NfSO1 [https://perma.cc/842L-5CQQ]. Unfortunately, the ability to devote fewer resources to teaching skills continues to this day. In the 2017-2018 academic year, only $52 \%$ of schools paid entry-level LRW professors the same salary as entrylevel doctrinal professors, even when both positions were traditional tenure track, and nearly two-thirds of law schools paid entry-level LRW professors with something less than traditional tenure-track positions less than entry-level doctrinal professors. Alyssa Dragnich et. al., Report of the 2017-2018 Institutional Survey, Legal Writing Inst. 1, 143, https://bit.ly/3fjaDbQ [https://perma.cc/X62LRDNZ] (last visited Dec. 2, 2019).

29. BILEK ET AL., supra note 28 , at 11 . Indeed, Georgetown Professor Tiffany Jeffers refers to the Legal Writing and Research track as the "Pink Ghetto" because of the existing hierarchies and inequities in status and pay for those who teach in this discipline. Tiffany Jeffers, The Choice to Stay in the Pink Ghetto, 23 Legal Writing: J. Legal Writing Inst. 41, 43 (2019).

30. Brooke J. Bowman, Researching Across the Curriculum: The Road Must Continue Beyond the First Year, 61 OKLa. L. Rev. 503, 544 (2008).

31. Id.

32. BILEK ET AL., supra note 28, at 2 (noting that "[t]he MacCrate Report certainly was not the first examination of the degree to which law schools do (or do not) prepare students for legal practice. As Task Force Chair Bob MacCrate has observed, the Report built on prior studies like the Reed Report of 1921, the work of Jerome Frank in the early 20th Century, and a 1979 report by the Section of Legal Education and Admissions to the Bar."). 


\section{B. Call for a Change in Legal Education Heats Up: 1992-2007}

Over the last three decades, various constituencies have called for reform in legal education or have taken steps to implement reform..$^{33}$ The first call for reform in this era was the Legal Education and Professional Development-An Educational Continuum (Report of the Task Force on Law Schools and the Profession: Narrowing the Gap, 1992), known as the MacCrate Report. ${ }^{34}$ The MacCrate Report formulated a compendium of ten lawyering skills required of any "well-trained generalist to practice law competently and professionally." ${ }^{35}$ In brief, the "Fundamental Lawyering Skills" describe functions performed by lawyers in all or nearly all areas of legal practice: (1) problem solving; (2) legal analysis and reasoning; (3) legal research; (4) factual investigation; (5) communication; (6) counseling; (7) negotiation; (8) litigation and alternative dispute-resolution procedures; (9) organization and management of legal work; and (10) recognition and resolution of ethical dilemmas. ${ }^{36}$

For the fundamental lawyering skill of legal research, the MacCrate Report included three sample goals for students: (1) learning real-world problem-solving skills, including efficiently and effectively conducting legal research; (2) learning the legal research process, including identifying issues, researching those issues, and communicating the results of their research; and (3) learning the difference between primary and secondary sources and when to conduct research in those sources so as to find the best, most current authority. ${ }^{37}$

Finally, the MacCrate Report recommended that each law school "develop a coherent agenda of skills instruction." 38 It also called upon law schools to provide "opportunity for students to perform lawyering tasks with appropriate feedback and self-evaluation [and] reflective evaluation of the students' performance by a qualified assessor." 39

But not all commentators felt that increasing research instruction was necessary. For instance, Wallace Loh, then Dean at the University of Washington Law School, noted in 1995 that it was fair

33. Hamm et al., supra note 1, at 359-65.

34. ABA Section on Legal Educ. \& Admissions to the Bar, Legal Education and Professional Development-An Educational Continuum (1992) [hereinafter MacCrate Report].

35. Id. at 125 .

36. Id. at $138-40$.

37. Bowman, supra note 30, at 521-22.

38. MacCrate Report, supra note 34, at 331.

39. Id. 
to assume that all law schools provided their students with a good grounding in legal research. ${ }^{40}$ And, of course, the responses to the MacCrate Report were too little to be considered a full reform in the delivery of legal education. ${ }^{41}$ In fact, many law schools still bifurcate their curriculum and faculty. ${ }^{42}$

Fifteen years after the MacCrate Report's call for a sea change in legal education, the latest calls for reform began with the publication of Educating Lawyers: Preparation for the Profession of Law ("Carnegie Report") 43 and then Best Practices for Legal Education ("Best Practices"). ${ }^{44}$ Both the Carnegie Report and Best Practices called for schools to integrate skills instruction rather than treating those skills as separate subjects. ${ }^{45}$ The independent Carnegie Report found that the call for comprehensive reforms advocated by the MacCrate Report had largely gone unheeded. ${ }^{46}$

Robert MacCrate himself wrote the Forward to Best Practices. ${ }^{47} \mathrm{He}$ noted that the authors had

distilled out of the continuing dialogue [surrounding the need for
reform of legal education] a consensus of understanding of an
alternative vision of all the components of legal education, based
on educational research and scholarship: an integrated combina-
tion of substantive law, skills, and market knowledge, and embrac-
ing the idea that legal education is to prepare students for the
practice of law . . . 48

The Carnegie Report noted that although more skills and values courses were being offered, those courses tended to be isolated and undervalued. ${ }^{49}$ The authors asserted that "[t]he relatively subordinate place of practical legal skills ... is symptomatic of legal

40. Loh, supra note 24 , at 509.

41. Hamm et al., supra note 1 , at 363 (noting that the crux of the problems found by Carnegie report was that little had changed since the MacCrate Report).

42. Erwin Chemerinsky, Reflections of the Future of Legal Education, 13 FIU L. Rev. 215, 219 (2018); see also Meredith Aden \& Ted Becker, Report of the 2017-2018 Institutional Survey, Legal Writing Inst. 7-13, available at https:// bit.ly/3iLJpgS [https://perma.cc/K2P5-V6D5] (last visited July 19, 2020).

43. Carnegie Foundation Report, supra note 1, at 27-28.

44. Roy Stuckey et al., Best Practices for Legal Education: A Vision and A Roadmap (2007); Building on Best Practices: Transforming Legal Education in a Changing World 3 (Deborah Maranville et al. eds., 2015) [hereinafter Best Practices].

45. Id. at 71-73; Carnegie Foundation Report, supra note 1, at 28-29.

46. Hamm et al., supra note 1, at 363.

47. Best Practices, supra note 44, Forward at vi.

48. Id. (emphasis added).

49. BILEK ET AL., supra note 28, at 12 (noting that "the use of adjuncts and lower-status faculty to teach courses send the signal to students that those courses are less valuable"). 
education's approach to addressing problems and framing remedies." 50

\section{Call for a Change in Legal Education Since 2007: We Haven't Changed Enough}

Since the Carnegie Report and Best Practices, critics have continued to posit that schools focus too much energy on delivering content and too little on helping students develop techniques for becoming better learners. ${ }^{51}$ One commentator noted that

Law schools' curricular design, structure, and organization is centered upon the teaching of substantive knowledge (such as torts, criminal law, etc.) and cognitive knowledge (such as "learning to think like a lawyer"). Expertise and skills have been, historically, a low priority. Unsurprisingly, "students encounter this practicebased kind of learning through quite different pedagogies from the way they learn the theory. They are often taught by faculty members other than those from whom they learned about the first, conceptual apprenticeship. In this second apprenticeship,

50. Stephen M. Johnson, Teaching for Tomorrow: Utilizing Technology to Implement the Reforms of MacCrate, Carnegie, and Best Practices, 92 Neb. L. Rev. 46, 51 (2013) (quoting Carnegie Foundation Report, supra note 1, at 7).

51. Elizabeth M. Bloom, Creating Desirable Difficulties: Strategies for Reshaping Teaching and Learning in the Law School Classroom, 95 U. DET. MERCY L. Rev. 115, 118 (2018); Eli Wald, The Contextual Problem of Law Schools, 32 Notre Dame J.L. Ethics \& Pub. Policy 281, 293-94 (2018); Elizabeth Adamo Usman, Making Legal Education Stick: Using Cognitive Science to Foster LongTerm Learning in the Legal Writing Classroom, 29 Geo. J. Legal Ethics 355, 359 (2016) ("In response to mounting criticism, law schools have been shifting their focus to producing 'practice-ready' attorneys."); BILEK ET AL., supra note 28, at 2; Flanagan, supra note 4, at 110-11 ("Law schools have been thoroughly, and deservedly, criticized for failing to teach in a manner that helps students learn. However, law schools are not isolated examples of education failing to adopt advances in cognitive and behavioral science; most of higher education has not fully implemented the best, most innovative practices that reflect what we now know about learning and memory. Cognitive and behavioral science related to learning and memory has advanced considerably in the last twenty-five years, but these advances have been isolated from practical applications in the field of professional education. Similarly, there have been limited advances in the theoretical framework of professional education; law school is still relying on outdated models of pedagogy and andragogy that have demonstrated weaknesses. Legal education needs a new theoretical framework based on advances in the science of learning, a framework that is flexible enough to evolve with changes to the profession and to the science of learning. The Carnegie Report and Best Practices showed the legal academy what needs to be done, but ten years after their publication, law schools have failed to implement the reimagining of the curriculum needed to meet the new reality of legal practice."). 
students learn by taking part in simulated practice situations, as in case studies, or in actual clinical experience with real clients. ${ }^{52}$

Noted constitutional law scholar and the current Dean of Berkeley Law, Erwin Chemerinsky summed it up this way: "Every major study that has been done about legal education for decades confirms that law schools do not do enough to give law students the skills that are necessary for the practice of law." 53 Nonetheless, much of the law school curriculum remains focused on doctrinal casebook courses, to the derogation of courses teaching the practical skills needed for the practice of law. ${ }^{54}$ Indeed, students still spend the majority of their time during law school reading carefully curated legal opinions in order to prepare for class. ${ }^{55}$

The ABA again joined in the calls for reform. By 1996 it began to recognize the importance of legal research and began mandating that law schools include instruction in legal research. ${ }^{56}$ Then in $2014,{ }^{57}$ the ABA required law schools to adopt learning outcomes

52. Wald, supra note 51, at 293-94; see also Michael Hunter Schwartz, Teaching Law by Design: How Learning Theory and Instructional Design Can Inform and Reform Law Teaching, 38 SAN Diego L. Rev. 347, 350 (2001) (noting that the dominant method of instruction in legal education has "persisted even in the face of the explosive evolution of learning theory throughout the twentieth century and the rise, in the second half of the century, of the field of instructional design, a field devoted to the systematic and reflective creation of instruction").

53. Chemerinsky, supra note 42, at 219.

54. Id.; see also Tonya Kowalski, True North: Navigating for the Transfer of Learning in Legal Education, 34 Seattle U. L. Rev. 51, 52-53 (2010).

55. Ann Sinsheimer \& David J. Herring, Lawyers at Work: A Study of the Reading, Writing, and Communication Practices of Legal Professionals, 21 LEgaL Writing: J. Legal Writing Inst. 63, 80 (2016). During an ethnographic study using upper-level law students as observers of attorneys in Pittsburgh from several practice groups, a second-year student observed: "The types of documents L read varied based on what type of case she was working on and how big her role was within the case. What surprised me most about this was how little time she actually spent reading judicial decisions. While I was there, I witnessed her reading mostly treatises, statutes, case summaries, emails, discovery documents, and secondary sources. She did read some judicial opinions while I was there, particularly when she was researching a legal issue, but not as frequently as one would expect based on the strong focus on what seems like only judicial opinions in law school. A lot of L's time was actually spent reading documents that most law students never see, such as discovery documents, business documents, contracts, and bids." This observation was representative of each observer's experience. 1996).

56. Standards \& Rules of Procedure Standard 302(b) (Am. Bar Ass'N.

57. ABA Section on Legal Educ. \& Admissions to the Bar, Transition to and Implementation of the New Standards and Rules of ProceDURE FOR ApProval of Law Schools (2014), https://bit.ly/2AOBJcG [https:// perma.cc/KV8T-FEYY]. 
that would, at a minimum, require competency in legal research. ${ }^{58}$ Yet, the path to adopting these standards was "a long and tortuous one, in part because of the concerns about obtaining the proper balance between traditional methods of legal education and a shift toward more skills education."59 Indeed, the subcommittee charged with drafting and revising the standards related to learning outcomes, the Student Learning Outcomes Subcommittee, felt that the traditional method of legal education should stay at the heart of the law school curriculum. ${ }^{60}$

\section{Call for Change from Outside the Academy: Recent Graduates and Their Employers Decry the State of Legal Education}

The critics of legal education, however, are not limited to the ABA and academics. Law students and recent graduates are likewise dissatisfied with the current state of American legal education. In 2011, a Survey of Law School Engagement revealed that "[f]orty percent of students felt their legal education had contributed only some or very little to their acquisition of job or work-related knowledge and skills."61 A 2016 Gallup poll questioned "4,000 adults who received a postgraduate degree between 2000 and 2015.",62 Law school graduates polled the lowest in satisfaction among all graduate degree holders. ${ }^{63}$ Fewer than a quarter of the respondents strongly agreed that law school "was worth the cost," and only 20 percent strongly agreed that law school "prepared me well for life outside of graduate school." 64

Employers are likewise dissatisfied with recent graduates' practical skills. A recent survey of 300 hiring managers and partners at large and small law firms across the United Stated engaged in all types of practice revealed that 95 percent of those hiring managers and partners believed recent law school graduates lacked nec2014).

58. Standards \& Rules of Procedure Standard 302 (Am. Bar Ass'N.

59. Steven C. Bahls, Adoption of Student Learning Outcomes: Lessons for Systemic Change in Legal Education, 67 J. Legal Educ. 376, 377 (2018).

60. Id. at 382.

61. E. Scott Fruehwald, Think Like a Lawyer: Legal Reasoning for Law Students and Business Professionals ix-x (2013) (quoting A. Benjamin Spencer, The Law School Critique in Historic Perspective, 69 WASH. \& LeE L. REV. 1949, 2014 (2012)).

62. Zac Auter, Few MBA, Law Grads Say Their Degree Prepared Them Well, Gallup (Feb. 16, 2018), https://bit.ly/3gPDwxz [https://perma.cc/WH2Q-4VBH].

63. Id.

64. Id. 
essary practical skills at the time they were hired. ${ }^{65}$ While the respondents found that most graduates had basic research skills, their advanced legal research skills were lacking. ${ }^{66}$ The study also noted that young associates spend between 40 and 60 percent of their time on research tasks, so over 80 percent of survey respondents found research skills to be highly important. ${ }^{67}$ Yet, the survey determined that drafting pleadings and advanced legal research skills-those skills beyond conducting basic case law and statutory research-"presented the largest gap between the importance of proficiency and the percentage of new associates actually possessing those skills." 68

There is a long history of calls for fundamental changes in the way law schools are structured and in the methods of teaching. ${ }^{69}$

65. LexisNexis, Hiring Partners Reveal New Attorney Readiness FOR Real World Practice 1 (2015), https://bit.ly/3fmvPyn [https://perma.cc/ 29WE-BZM8 ] (last visited July 11, 2020).

66. Id. at 3 .

67. Id.

68. Id. at 4 .

69. Adamo Usman, supra note 51, at 359-60 ("In response to mounting criticism, law schools have been shifting their focus to producing 'practice-ready' attorneys. Practical skills education in preparing students to be practicing attorneys resides at the heart of such an educational mission. In fact, most recently, the American Bar Association ... has set forth a standard that requires law schools to make at least six credits of 'experiential' learning mandatory in the curriculum. With such a focus, legal education has moved beyond teaching to the end of the semester exam or even the bar exam but instead has shifted to a focus on longterm skill development that will aid a student in practice."); Caroline L. Osborne, The State of Legal Research Education: A Survey of First-Year Legal Research Programs, or "Why Johnny and Jane Cannot Research," 108 L. Libr. J. 403, 419 (2016) ("Changes to the basic research curriculum must reinforce the importance of research within the practice of law. This means a research course to which students will assign importance in a risk/reward calculation and a course taught by an expert with sufficient time allocated to effectively teach the complexities of research. A continued lack of emphasis on research within the framework of legal writing or legal practice skills, combined with the information explosion, will continue to diminish the importance of research and will result in a loud and appropriate chorus from the bench and bar that '[new graduates can't research]." ); Carol McCrehan Parker, Writing Is Everybody's Business: Theoretical and Practical Justifications for Teaching Writing Across the Law School Curriculum, 12 Legal Writing 175, 177 (2006) ("Research into the acquisition of expertise demonstrates the importance of sustained, deliberate practice in facilitating learning. This research suggests that even the most effective first-year writing sequence cannot provide sufficient opportunities for students to practice skills in research, analysis, and writing. Additional experience in research and writing in classes throughout the curriculum will better prepare students for lifelong learning in their profession."); see Bahls, supra note 59, at 395 (explaining that the committee charged with drafting the ABA standards related to learning outcomes noted that two well-respected legal educators asserted that "teaching and exams have not changed much in the past generation and that there are great opportunities for fundamental changes in the way teaching is conducted"). 
The major studies indicate that law students need more skills instruction, ${ }^{70}$ students are dissatisfied with the lack of skills instruction, ${ }^{71}$ employers are dissatisfied with new graduates' research skills, ${ }^{72}$ and academics note that law school curriculums need to change. ${ }^{73}$ And in the context of research instruction, the critics' common refrain is that law students lack even the necessary legal research skills to practice successfully once they leave school.

\section{The Need For Better Research Instruction}

The call for a change in legal education has also included a small-but-growing demand for reform of the delivery of legal research skills instruction. ${ }^{74}$ These calls from the academy recognize that faulty assumptions underlie curricular decisions about legal research instruction. At the same time, the realities of conducting legal research have changed since the curricular decisions regarding legal research instruction were made. These faulty assumptions and the lack of emphasis on legal research, in turn, have led to a growing dissatisfaction with recent graduates' legal research skills at the same time as the rapid expansion of legal research resources and changes in the practice of law.

70. Chemerinsky, supra note 42, at 219.

71. Jason G. Dykstra, Beyond the "Practice Ready" Buzz: Sifting Through the Disruption of the Legal Industry to Divine the Skills Needed by New Attorneys, 11 Drexel L. Rev. 149, 187-89 (2018).

72. LeXISNeXIs, supra note 65 , at 1.

73. Mark F. Kightlinger, Two and A Half Ethical Theories: Re-Examining the Foundations of the Carnegie Report, 39 OHIо N.U. L. Rev. 113, 131-32 (2012) ("Perhaps the largest body of secondary literature on the Carnegie Report deals with concerns about teaching practical skills to novice lawyers. Numerous scholars agree with the Carnegie Report's view that training in legal skills is important and that law schools do not provide enough of such training. One scholar has argued for more training in legal research and another has argued for more legal clinics. Several scholars follow the Carnegie Report in asserting that law schools place insufficient emphasis on legal writing skills. For example, one has recommended that law schools teach first-year law students to draft contracts, another that schools should teach writing in a manner that emphasizes different types of thinking skills, and others that instruction in writing should be part of a "General Practice Skills' course.").

74. Id.; Jamie J. Baker, Posner, Richard A. Divergent Paths: The Academy and the Judiciary Book Review, 108 L. LiBr. J. 467, 468 (2016) (book review) ("Like many other suggestions for legal writing reform, legal research is given short shrift. In addition to Posner's call for legal writing reforms, there should also be an emphasis on legal research to help inform the very realism that he would like law students to employ.”). 


\section{A. Faulty Assumptions Underlie the Curricular Decisions Regarding Legal Research}

Within the last decade or so, scholars have noted a continued lack of emphasis on research instruction within law school curricula. ${ }^{75}$ The lack of emphasis is based in part on the history of research instruction's inclusion in legal writing curriculum and faulty assumptions by doctrinal faculty about the ease of teaching and acquiring legal research skills. ${ }^{76}$

While faculty who teach lawyering skills have made progress toward understanding the importance of what they teach, others do not always see legal research as a key skill in need of emphasis. ${ }^{77}$ Often, others see legal research as intuitive, straightforward, or non-intellectual, as something that can be easily mastered. ${ }^{78}$ And often the curriculum already incorporates first-year legal research and writing courses, so law schools feel that the skills have been taught. ${ }^{79}$ The assumptions that legal research skills are easy to master and have already been given sufficient coverage for students to master the skills, however,

are incorrect because they fail to account for the links between research skills and the metacognitive processes used in other lawyering tasks, such as factual investigation, development of interdisciplinary expertise, and the management of other document-intensive lawyering processes (such as e-discovery or digital due diligence). Good research habits-developing and documenting a methodical research strategy, paying close attention to detail, evaluating value and reliability, and being efficient with one's time and resources-carry over into other areas of daily practice. ${ }^{80}$

75. Tung, supra note 24; Barbara Glesner Fines, Out of the Shadows: What Legal Research Instruction Reveals About Incorporating Skills Throughout the Curriculum, 2013 J. Disp. Resol. 159, 160 (2013); Patrick Meyer, Law Firm Legal Research Requirements and The Legal Academy Beyond Carnegie, 35 WhitTIER L. REv. 419, 420 (2014).

76. Tung, supra note 24 , at 286 . I would posit that no professor or librarian tasked with teaching incoming law students the necessary legal research skills belies that the skills are either easy to teach or easy to learn and acquire.

77. Id.

78. Id.

79. Id.

80. Id.; Glesner Fines, supra note 75, at 160 ("While external voices such as ABA accreditation standards and surveys of the practicing bar have long-recognized importance of the skills of legal research, evidence of the importance of the skill in the law school curriculum is mixed. If asked, most faculty members will agree that a given skill, such as legal research, is important. However, for that skill to be integrated into the curriculum in a way that will substantially affect graduate 
But "[1]egal research is not an intuitive skill. Yes, one has to have intellectual curiosity to begin with; but it is a skill that requires instruction, practice, and more practice to develop confidence and to do it well." ${ }^{81}$ Legal research is a complex skill, one that is more of an art than a checklist. ${ }^{82}$ To be a competent attorney, one must conduct research with thoroughness and accuracy, resolve the client's issues adequately, and balance time constraints for the current research project with all other tasks that must be completed. ${ }^{83}$ Moreover, one must also understand where sources are available and ensure that the sources found are current and still good law. ${ }^{84}$

Law students, however, are research novices and lack the context for approaching legal research. While their ability to find information via Google is not an issue, their ability to conduct legal research - to "dig deep, to think critically, to evaluate the information they are finding for fit, and to engage in the legal analysis required in the practice of law"-is lacking. ${ }^{85}$ They "simply do not understand the mechanics of researching[.]" 86 Many first-year law students have received no formal research training at all prior to matriculating in law school. ${ }^{87}$

Law students also lack a conceptual understanding of the law or contextual tools to conduct legal research when they enter law school. ${ }^{88}$ They lack an understanding of where legal information is kept, of how legal information is or has been organized, and of the specialized legal vocabulary necessary to effectively conduct legal research. ${ }^{89}$ Indeed, students entering law school are more comfortable using general search engines to conduct research than using

competencies, the skill must be important enough in the hierarchy of the faculty and curriculum to justify the costs of curricular change.").

81. Filippa Marullo Anzalone, Some Musings on Teaching Legal Research, 20 Legal Writing: J. Legal Writing Inst. 5, 6 (2015); see also Bowman, supra note 30 , at 551 .

82. Bowman, supra note 30 , at 514-15.

83. Id. at 514.

84. Id. at 515 .

85. Osborne, supra note 69 , at 407.

86. Meyer, supra note 75 , at 451.

87. During August and September 2011, 712 incoming first-year law students were surveyed about their undergraduate experiences related to research and writing. Ellie Margolis \& Kristen E. Murray, Say Goodbye to the Books: Information Literacy as the New Legal Research Paradigm, 38 U. DAYTON L. REv. 117, 132-33 (2012). "Most of the respondents received some form of research training; $28.8 \%$ of the respondents said that they had received no formal research training at all." Id. at 135 .

88. Bowman, supra note 30, at 523-24; Meyer, supra note 75, at 420.

89. Bowman, supra note 30 , at 532-36. 
paid services or books..$^{90}$ Additionally, only about one-third of students "evaluate the scope, content, and organization of online databases; consult with available sources to generate key words and search terms; and evaluate the purpose of potential sources." ${ }^{91} \mathrm{Fi}-$ nally, most students end their research when they feel they have found enough sources to competently discuss the topic rather than when they have ensured that their research is complete and all their sources are still good law. ${ }^{92}$

The students need to be explicitly taught the link between legal research and legal analysis, and they must learn basic research skills before moving to more difficult research tasks. ${ }^{93}$ Thus, there is a disconnect between the assumptions made by those who make curricular decisions about the ease of teaching legal research and the skills of the students who must learn how to research.

\section{B. Law Students and Employers are Dissatisfied with Graduates' Legal Research Skills}

This lack of importance placed on legal research instruction based on faulty assumptions has led to dissatisfaction with the research skills of recent graduates, both among potential employers ${ }^{94}$ and among the current students receiving instruction..$^{95}$ A survey of law students revealed that 71 percent would like to see more connection between the substantive law and legal research in their sub-

90. Margolis \& Murray, supra note 87 , at $140-42$ (noting that "[g]eneral internet searching was clearly the most popular 'first choice' source- $61.2 \%$ of the respondents are most likely to conduct this type of search first").

91. Id. at $141-42$.

92. Id. at $147-48$.

93. Meyer, supra note 75 , at 420 .

94. Aliza B. Kaplan \& Kathleen Darvil, Think (and Practice) Like a Lawyer: Legal Research for the New Millennials, 8 Legal Comm. \& RHetoric: JALWD 153, 164 (2011) ("Law firms, judges, and practitioners are dissatisfied with the way new attorneys conduct research. The current state of legal research instruction fails to train students to adequately research the law. Because of the limited amount of time devoted to teaching legal research and the superficial nature of that instruction, law students graduate and fail to perform at the level required of them by their employers."); McCrehan Parker, supra note 69, at 178 ("At the same time that employers' expectations of new law graduates have increased, evidence indicates that preparation in research and writing in secondary and undergraduate schools has diminished."); Glesner Fines, supra note 75, at 160 ("Legal research skills have long been recognized as foundational to legal practice. Yet attorneys and law firm librarians consistently evaluate law students and new lawyers as deficient in legal research skills."); Yolanda P. Jones, Expansive Legal Research, 44 INT'L J. LEGAL INFO. 241, 255 (2016) ("It is common in legal research to see descriptions or depictions of students who were taught the basics of legal research in the first year of law school but who do not seem to have retained this information upon reaching their upper-level courses.").

95. Kaplan \& Darvil, supra note 94, at 168. 
stantive law courses. ${ }^{96}$ Moreover, law students "expect to graduate with a set of skills that will enable them to practice competently. Law schools have a responsibility to meet this expectation and to ensure that their students are trained not only to think like lawyers but also to practice like lawyers." 97 In 2015, 95 percent of the 300 hiring partners and senior partners who were surveyed reported that they believed recent graduates lacked the necessary practical skills, such as advanced research skills, and 86 percent believed research skills were highly important for young associates. ${ }^{98}$

\section{The Landscape of Legal Research is Rapidly Changing}

To make matters even more difficult for students and newly minted attorneys, the relative lack of importance placed on research skills in the law school curriculum coincides with a rapid expansion in information and its availability that has changed the practice of law:

We are in an environment where research techniques generally and legal research techniques specifically are undergoing a significant transformation due to technological changes and the mass of information now available to attorneys. Technology presents a challenge with the proliferation of information that must be managed in an effective and efficient manner by the researcher. ${ }^{99}$

Indeed, one commentator noted that the "availability of legal information on the Internet has led to the law's equivalent of the Protestant Reformation."100 As legal information has become available to more people, legal research has transformed. ${ }^{101}$ There has been a "paradigm shift" from conducting legal research in books to understanding and navigating the world of electronic sources. ${ }^{102}$ The change in how legal research is conducted and the availability of legal sources is so marked that the Legal Writing Institute dedicated every essay in the twentieth edition of its journal

96. Id.

97. Id.

98. LeXisNexis, supra note 65 , at 1,3 .

99. Osborne, supra note 69 , at 406.

100. Amy E. Sloan, The 95 Theses: Legal Research in the Internet Age, 20 Legal Writing: J. Legal Writing Inst. 45, 45 (2015).

101. $I d$.

102. Ellie Margolis \& Kristen Murray, Mind the Gap, 20 Legal Writing: J. LegAl Writing InST. 25, 25 (2015); but see Meyer, supra note 75, at 451 (noting that research instruction should include teaching book-based research). 
to discussing this change and how best to approach it with law students. $^{103}$

Additionally, as legal research is conducted mostly or even exclusively online, students (or new attorneys with poor research skills) can fall prey to complacency and bias. ${ }^{104}$ The complacency computer research causes stems from a false sense of security. ${ }^{105}$ Search providers and tools will return results no matter how poorly conceived the initial search. ${ }^{106}$ Moreover, the bias from online research derives from placing too much trust in the results. ${ }^{107}$

\begin{abstract}
Students may believe that the powerful search engines will find all—or enough—relevant authorities simply because of the volume of results. If one search from a universal search bar with a few key words produced 894 cases, 231 statutory references, and over 10,000 secondary sources, surely the search was a success and the necessary documents are included! Narrowing these results with a few filters could bring the results down to 37 , which any student can easily scan. But the original search might have been so poorly conceived that the resulting list of authorities is incomplete or off-topic. ${ }^{108}$
\end{abstract}

Yet, "given the proliferation of online legal information, multiple systems through which to access it, and the high cost of mis-

103. Robert C. Berring, What a Long, Strange Trip It's Been, 20 Legal WrITIng: J. Legal Writing Inst. 9 (2015); Ian Gallacher, Not Seeing Our Brains: The Future of Legal Research, 20 Legal Writing: J. Legal Writing Inst. 13 (2015); Penny A. Hazleton, Searching for the Borders, 20 Legal Writing J. Legal WRITING INST. 17 (2015); Stefan Krieger, The Challenges of Using Electronic Resources to Solve Ill-Structured Legal Problems, 20 Legal Writing : J. Legal Writing Inst. 21 (2015); Margolis \& Murray, supra note 102; Marullo Anzalone, supra note 81; Linda S. Maslow, Researching on Solid Ground in a Changing Technological Landscape, 20 Legal Writing: J. Legal Writing Inst. 29 (2015); Mark K. Osbeck, Using Data Analytics Tools to Supplement Traditional Research and Analysis in Forecasting Case Outcomes, 20 Legal Writing: J. Legal Writing Inst. 33 (2015); Terrill Pollman, Introduction to Essays on Technology and Changes in Legal Research, 20 Legal Writing: J. Legal Writing Inst. 1 (2015); Jeane Frazier Price, You Make Me Feel Like Dancing: Students, Scholars, and Sources in the Law Library, 20 Legal Writing: J. Legal Writing Inst. 37 (2015); Suzanne Rowe, Out of the Glass Cockpit: Teaching Legal Analysis in Legal Research, 20 LEGAL Writing: J. Legal Writing Inst. 41 (2015); Sloan, supra note 100; Ronald Wheeler, Is This the Law Library or an Episode of the Jetsons?, 20 LEGAL WRITIng: J. Legal Writing Inst. 53 (2015); Michelle M. Wu, Technology and Future Directions for Law Libraries, 20 Legal Writing: J. Legal Writing Inst. 53 (2015).

104. Rowe, supra note 103 , at $41-42$.

105. Id. at 42.

106. $I d$.

107. $I d$.

108. $I d$. 
takes," being a competent legal researcher has become even more essential. ${ }^{109}$

Indeed, in examining the practical justifications for including writing instruction across the curriculum, one commentator noted "the explosion in availability of legal authority and other information that requires ever more skill and efficiency in selection and synthesis of appropriate authorities." 110 And to add another layer, the economics of law practice have changed. ${ }^{111}$ This reality has led to a call for structural changes in how research instruction is delivered to law students. ${ }^{112}$ The calls have been varied, but the fundamental similarity among the calls is that law schools must change how legal research skills are taught if graduates are to have the necessary skills they need to be practice ready. ${ }^{113}$

\section{The Call for Research Across the Curriculum}

Among these calls is one that could be broadened to best answer Best Practices' and the Carnegie Report's call to integrate legal skills instruction instead of treating it as a separate subject: research across the curriculum. ${ }^{114}$ This call for a structural change to

109. Am. Ass'n of Law Libraries, Principles and Standards for Legal ReseArch CoMPetency 2 (2013), https://bit.ly/3iXqpML [https://perma.cc/FV7SM2X9].

110. McCrehan Parker, supra note 69, at 178.

111. Id.; Dykstra, supra note 71 , at 188 .

112. "The common refrain that law students lack the most basic legal research skills is likely to continue until law schools make fundamental structural changes in the method of teaching legal research." Osborne, supra note 69, at 419; Kaplan \& Darvil, supra note 94, at 190 ("It is time to heed the calls for legal education reform. In our changing economy, new attorneys need to be properly trained in law school to be competent at providing effective legal services for their employers and clients. Law schools must remain open to and interested in legal reform; they must partner with practitioners to incorporate more practical skills into the law school curriculum. Updating how we teach legal research by making it accord more with how attorneys actually conduct and use legal research in practice will help accomplish this and will also more actively engage our Millennial students.")

113. "While many law schools trumpet their 'practice ready' bona fides, the conception of what constitutes a practice ready curriculum varies widely and its efficacy proves somewhat illusory." Dykstra, supra note 71 , at 185 ; see also Adamo Usman, supra note 51, at 360 ("Given the importance of long-term skill development to heed the call for the "practice-ready" attorney, it is time for the legal academy to pay closer attention to not just including a skills-based curriculum, but including a skills-based curriculum that is designed and taught such that students will retain the taught skills as they move forward to represent clients in practice.").

114. See generally Bowman, supra note 30. Other scholars have proposed different solutions, including requiring an advanced research course and making legal research a part of the bar exam. Meyer, supra note 75, at 457-58. Or creating a more robust stand-alone 1L legal research course. Osborne, supra note 69, at 417-18. Most recently, law librarians and legal research and writing professors 
the delivery of legal research instruction recognizes that limiting research skills instruction to a single first-year course does not allow students to become the experts in legal research skills the job market will demand of them. ${ }^{115}$ Instead, such courses provide students with only a foundation on which they can build; first-year courses "cannot provide the sustained practice over time that students need in order to become experts in legal analysis, research, and writing. Research in expertise has focused on the paths traveled by experts in various fields to examine what they know and how they came to know it." 116 The call also recognizes that research instruction fits neatly into every course law schools offer because research skills are foundational to the practice of law. ${ }^{117}$

\section{E. Challenges to Changing Legal Research Instruction}

Calls for changes in the delivery of legal research instruction have noted several challenges to incorporating such changes. First is a "general skepticism" about skills instruction. ${ }^{118}$

For some faculty, whose own connection to practice is thin and distant, a shift to emphasizing practice skills can threaten their sense of competence. Others may argue that it is unrealistic to develop practice-ready attorneys in three years of law school, no matter how capable a faculty would be of providing this training. Examining this issue through the lens of legal research lends additional insights into this skepticism. Faculty scholars, for whom one would presume research to be a core skill set, may have developed that skill in such an incremental and organic process that they may be unable to "unpack" the expertise they have or even recognize the sheer complexity of their expertise. This can cause an undervaluing of the skill itself. ${ }^{119}$

have noted dissatisfaction with legal research instruction, especially as it relates to the ABA mandated learning outcomes. Genevieve B. Tung, Collaboration Between Legal Writing Faculty and Law Librarians: Two Surveys, 23 Legal WritING: J. Legal Writing InSt. 215, 248-49 (2019).

115. McCrehan Parker, supra note 69, at 181.

116. $I d$.

117. Kaplan \& Darvil, supra note 94, at 181-82 ("Fortunately, legal research is a skill that is easily integrated. It can be taught in skills courses, like drafting, appellate practice, or trial advocacy. It can also be woven into practical trainings, like school-sponsored clinics or externship programs. Similarly, it can be integrated into substantive-law courses. A real effort must be made in all law school classes beginning in year one to ensure that the research instruction the students receive in their research and writing classes will be further developed, refined, and reinforced in core curriculum courses.").

118. Glesner Fines, supra note 75, at 161.

119. Id. 
Second is the political tension caused by faculty competition for ownership over parts of their law school's curriculum. ${ }^{120}$ When responsibility for teaching skills is seen as "belonging" to a certain set of faculty, particularly when that set of faculty has a lower status in the hierarchy of the law school, "raising the priority of education in those skills is fraught with political tension."121 Some non-research-and-writing professors may feel that teaching skills belongs to "others" and the content of the courses they teach is "theirs." 22

Third is the attitude that in order to include skills instruction, something else must be jettisoned from a course. ${ }^{123}$ Fourth, as one call for instituting research across the curriculum noted, including research across the curriculum would face roadblocks from both an instructor perspective and an administrative perspective. ${ }^{124}$ Administratively the important skills of legal research are expensive: legal research instruction "requires considerable resources in terms of the curriculum, credit hours, financial resources, and delivery." ${ }^{25}$ Moreover, law schools must make decisions based on financial pressures. ${ }^{126}$ And from an instructor perspective, "incentive, personality, history, and inertia are all strongly against making any form of change ...."127

Finally, any large-scale curricular changes, such as incorporating legal research across the curriculum, would require a commitment and understanding from the entire faculty. ${ }^{128}$ Each faculty

120. $I d$.

121. $I d$.

122. Bowman, supra note 30 , at $548-49$.

123. Glesner Fines, supra note 75, at 161; see also Louis Deslauriers et al., Measuring Actual Learning Versus Feeling of Learning in Response to Being Actively Engaged in the Classroom, Proc. NAT'L ACAD. SCI. U.S. 19251, 19251 (Sept. 24, 2019), https://bit.ly/32CDbKJ [https://perma.cc/94HF-AWA5] ("Instructors cite many obstacles preventing them from adopting active teaching strategies, such as insufficient time, limited resources, a lack of departmental support, concerns about content coverage, and concerns about evaluations of their teaching.").

124. Bowman, supra note 30, at Part II; see also Bahls, supra note 59, at 405 (noting that "doctrinal faculty members disproportionally hold tenure rights and voting rights on curricular issues. As such, with their more traditional way of thinking about legal education, they are the most powerful and decisive voices at American law schools.").

125. Bowman, supra note 30 , at 543-44.

126. Id. at 545 .

127. Ian Gallacher, My Grandmother Was Mrs. Palsgraf: Ways to Rethink Legal Education to Help Students Become Lawyers, Rather Than Just Thinking Like Them, 46 CAp. U. L. Rev. 241, 261 (2018).

128. Bowman, supra note 30, at 549; Tung, supra note 114, at 161-62. The necessary commitment to changing law schools' curriculum underpinned the ABA's adoption of the standards relating to learning outcomes. Bahls, supra note 59 , at $384-85$. 
member would need to commit to the idea that students graduating from their school must be competent researchers. ${ }^{129}$ Then, non-research-and-writing teachers would need to abandon the assumption that all the research instruction students need is included in the first-year legal research and writing course or legal research course. ${ }^{130}$ Non-research-and-writing teachers would also need to understand the skills and competencies taught in the first year and then examine how they could further develop and reinforce those skills in their upper-level courses. ${ }^{131}$

To illustrate, students enter law school with significant barriers to becoming competent researchers after a single year of legal research instruction. ${ }^{132}$ Yet, in incorporating legal research instruction across the curriculum, schools would better prepare their graduates for practice by reinforcing research skills and stressing the importance of research skills to the novice legal researchers.

\section{The Legal Research Skills a Competent Novice Attorney NeEds to Have}

Unlike 1890 when new attorneys could depend on learning the skills necessary to practice law during the early years of their practice, ${ }^{133}$ and despite The American Association of Law Schools' recent assertion that law schools do not train lawyers, ${ }^{134}$ graduates today must be ready to hit the ground running. ${ }^{135}$ During the last two decades, the employment world for newly minted attorneys has changed drastically. ${ }^{136}$ The legal market's changes have been fueled by assorted changes to how legal services are provided

129. Bowman, supra note 30 , at 549 .

130. $I d$.

131. Id. This is not to say that legal research skills could not be included in traditionally doctrinal courses. I would argue that it would be even more beneficial to law students to begin teaching them the skills and the intersection between legal research and legal analysis early and often in all their coursework.

132. Id. at Parts II \& III.

133. Hammond et al., supra note 1, at 329-30.

134. Bahls, supra note 59, at 388 (citing Letter from H. Reese Hansen, President of the AALS, to Hewlett H. Askew, ABA Consultant on Legal Educ. (June 1, 2010), https://bit.ly/302YIJx [https://perma.cc/22K6-4EL7]).

135. Dykstra, supra note 71, at 161; Marullo Anzalone, supra note 81, at 5.

136. Dykstra, supra note 71, at 161; Bahls, supra note 59, at 397 (noting that the 2014 amendments to Standard 301 were "intended to send a signal to law schools that it is not adequate to assume that future employers will prepare students for the rigor of practice, but rather that it is the primary responsibility of law schools to provide a rigorous education that provides students with the skills to be members of the legal profession"). 
including technological advances that allow for the automation of many routine tasks and the disaggregation of legal services; enhanced client sophistication and cost-consciousness; global competition from off shoring routine legal services; the rise of the domestic gig economy, creating a new wave of home-shoring legal services; and competition from non-traditional legal services providers. In the face of declining revenues, rapid systemic changes, and burgeoning competition from near and far, law firms have shuttered many of the traditional mentorship opportunities for new attorneys. ${ }^{137}$

Because of "the heightened competition for jobs, newly minted lawyers need to emerge from law school both readier for practice and better prepared to immediately enhance profitability for their employers, clients, or contractors." 138 Today, most attorneys will be in private practice, and most likely in a small or solo practice. ${ }^{139}$

In the context of legal research, attorneys must understand the research challenges they will face: which research service to subscribe to, how to use the tools the local or state bar provides for researching, how to use practice guides and tools for transactional practice and counselling clients, where to find forms and dockets, and how to conduct factual research into businesses and people. ${ }^{140}$ Also, attorneys need to understand where the law can be found and grasp the differences in legal research providers' services. ${ }^{141}$ When attorneys begin legal research, they must have an understanding of what types of material different sources contain, which sources to

137. Dykstra, supra note 71 , at 149 .

138. Id. at 161.

139. Id. at 187-88 ("In the last three decades, the percentage of lawyers engaged in private practice steadily rose to approximately $75 \%$ of all attorneys. In contrast, $8 \%$ of all attorneys work in government and a paltry $1 \%$ work in legal aid or as public defenders. Accordingly, most new lawyers are destined to enter private practice. Further, almost three-quarters of private practitioners are in a solo practice or are members of small firms. Thus, the likely practice setting for most new attorneys seems relatively straightforward: most new attorneys will enter private practice by either joining small firms or starting solo practices.").

140. See Tung, supra note 24, at 302.

141. Marullo Anzalone, supra note 81, at 5 ("Students need to acquire legal skills to hit the ground running in their jobs and internships. To master the skill of legal research, students need to appreciate that "the law" can be found in many places and on many platforms. Students also need to grasp that not all research services are equally robust or reliable. For example, although many government websites contain a veritable wealth of information, students should understand both the advantages and limitations of these resources. Although "free" to the user, many government websites may not be as quickly updated as some of the more expensive research services that are commercially published.”). 
search, where those sources are available, and how to best search each source. ${ }^{142}$

One ethnographic study revealed that when attorneys research, they move between different source types and deal with competing concerns during the research process. ${ }^{143}$ Specifically, attorneys move from books to internet sources and from free or low-cost sources to subscription services while researching. ${ }^{144}$ Attorneys also deal with constant interruptions while researching and while constantly problematizing-asking themselves whether a source was useful and how it might solve the client's problems. ${ }^{145}$ This last aspect is necessary as attorneys must interact with the legal authorities they find with solving the client's problems in mind. ${ }^{146}$

Attorneys must also develop a research strategy, a research plan, and adapt that plan as their research reveals more issues or answers. ${ }^{147}$ In line with this, practitioners must also interact with a wide variety of secondary sources and find resources in a free-form manner to teach themselves unfamiliar legal areas and to locate relevant primary authority. ${ }^{148}$ Attorneys must find both legal and non-legal authorities related to solving the client's problems. "To efficiently navigate primary authority, practitioners rely on editorial enhancements such as synopses, headnotes, and key numbers, and readily utilize citators." 149

More specifically, the American Association of Law Libraries ("AALL") has identified a comprehensive set of principles and standards that a legal researcher must possess in order to be competent. ${ }^{150}$ The AALL has advanced five principles for competency in legal research: a successful legal researcher must (1) possess "foundational knowledge of the legal system and legal information sources"; (2) gather "information through effective and efficient research strategies"; (3) "evaluate[ ] information" critically; (4) apply "information effectively to solve a specific issue of need"; and (5) distinguish "between ethical and unethical uses of information, and understand[] the legal issues associated with the discovery, use, or application of information." 151 Each of these principles is essential

142. Bowman, supra note 30, at 524 .

143. Sinsheimer \& Herring, supra note 55, at 84-88.

144. Id.

145. Bowman, supra note 30 , at 524 .

146. Id. at 515-16.

147. Id.

148. Dykstra, supra note 71 , at 193.

149. Id. at 195.

150. Am. Ass'N of LAw Libraries, supra note 109, at 1-2.

151. Id. at 1 . 
and measurable for AALL advanced standards and competencies. $^{152}$

\section{The Current Placement of Legal Research INSTRUCTION}

The majority of American law schools continue to teach legal research where they have for the past several decades: as part of a first-year legal research and writing course. This continued curriculum is in spite of the calls for reform and the explosion of information and in spite of calls to create graduates who are competent legal researchers. But given the changes wrought by computer-assisted legal research and incoming students' lack of preparedness to conduct the type of research and analysis necessary to be a competent legal researcher, the current placement of legal research instruction is insufficient to create competent graduates.

\section{A. Legal Research Instruction Receives One Credit-Hour in the First Year}

The placement of legal research instruction in law school curriculums has remained relatively constant for the last fifteen years. Beginning in 1999, the two major organizations dedicated to supporting and improving legal research and writing, the Legal Writing Institute and the Association of Legal Writing Directors, have collected data on program design, curriculum, salary, workload, and status issues. ${ }^{153}$ Almost all law schools in the United States participate in these surveys. The data collected by these surveys reveals that there have been few shifts in the placement of legal research instruction and little movement toward offering research instruction beyond the basic first-year legal research and writing courses.

The majority of schools continue to include legal research instruction as part of an integrated legal research and writing course offered during the first year. ${ }^{154}$ Eighty percent of the respondent

152. Id. at 2.

153. $A L W D / L W I$ Survey, Legal Writing Inst., https://bit.ly/2OeW8uy [https://perma.cc/HEV3-GVMW] (last visited Dec. 2, 2019).

154. This is not to imply that all schools teaching legal research as part of an integrated legal research and writing course use the same methods of instruction or have the same professor teaching all the skills. There are at least three different models of providing legal research instruction in an integrated course (an integrated legal research and writing course, in which one professor teaches everything; an integrated course co-taught by Legal Writing faculty and librarians; and an integrated course taught by Legal Writing faculty with guest lectures by librarians). Nor is this to suggest that one method of instruction is better. "There are as many opinions on each of these models as there are people teaching legal research. 
schools integrated legal research instruction into their first-year legal research and writing course during the 2003-2004 academic year. ${ }^{155}$ The most recent survey reveals that 79 percent of the respondent schools integrated legal research instruction into their first-year legal research and writing course during the 2017-2018 academic year. ${ }^{156}$ During the intervening years, the percentage of schools integrating research instruction into their first-year legal research and writing course fell to a low of 74.1 percent in the 2016-2017 $7^{157}$ academic year and reached a high of 86.5 percent during the 2013-2014 academic year. ${ }^{158}$

While both a greater number and a higher percentage of schools are now offering an advanced research course as part of their legal research and writing programs, the number and percentage of schools requiring students to take an advanced research course to satisfy a graduation requirement ${ }^{159}$ has changed little: the majority of law schools still do not require any advanced research instruction for their students to graduate. In the 2003-2004 academic year, 36 schools (19.8 percent of responding schools) offered an advanced research course and 6 schools (3.4 percent of responding schools) required an advanced research course. ${ }^{160}$ By the 2013-2014 academic year, 50 schools (28.4 percent of responding schools) offered an advanced research course and 11 schools $(6.2$ percent of responding schools) required an advanced research

Some strongly favor stand-alone research courses on the grounds that only a dedicated class can convey the breadth of the subject. Others advocate for integrated models, emphasizing the recursive project of gathering, analyzing, and using legal information." Tung, supra note 114, at 228.

155. Kristin Gerdy \& Toni Berres-Paul, ALDW/LWI 2004 Survey Results, LEGAL Writing Inst., https://bit.ly/3eqQ7FD [https://perma.cc/D3BC-4MCA] (last visited Dec. 2, 2019).

156. See Aden \& Becker, supra note 42, at 21.

157. Jodi Wilson \& Alyssa Dragnich, Report of the 2016-2017 Survey, LEGAL Writing INST., https://bit.ly/3iYZ1xA [https://perma.cc/327Z-J9B4] (last visited Dec. 2, 2019)(showing that of the 182 schools that responded to the survey, only 135 integrated research instruction into the first year legal research and writing course).

158. George Mader \& Marci Rosenthal, 2014 National Survey Results, LEGAL WRITING INST., https://bit.ly/2Wb8SH9 [https://perma.cc/Q7KD-HS74] (last visited Dec. 2, 2019).

159. This is an imperfect measure. The survey tallies only schools that require an advanced legal research course that satisfies the school's advanced writing requirement. It could be possible, of course, to require an advanced legal research course that did not satisfy the advanced legal writing requirement. That information, however, is not captured by the survey. The survey asks about the required legal research and writing courses at a school, so it does not capture information about schools that offer an advanced research course outside of the LRW program.

160. Gerdy \& Berres-Paul, supra note 155 , at 21. 
course. $^{161}$ In the 2017-2018 academic year, 12 schools required an advanced research course. ${ }^{162}$ That number, however, represents only seven percent of the respondent schools. Moreover, the number of schools offering an advanced research course has declined in recent years from a high of 59 schools (31.4 percent of responding schools) in the 2010-2011 academic year. ${ }^{163}$

The following chart indicates the scant shifts in the placement of legal research instruction from the 2003-2004 academic year to the 2017-2018 academic year.

\begin{tabular}{|l|l|l|l|l|l|l|l|}
\hline $\begin{array}{l}\text { Survey } \\
\text { year }\end{array}$ & $\begin{array}{l}\text { Number of } \\
\text { schools } \\
\text { responding }\end{array}$ & $\begin{array}{l}\text { Number } \\
\text { of schools } \\
\text { that } \\
\text { integrate } \\
\text { research } \\
\text { instruction } \\
\text { into 1L } \\
\text { LRW } \\
\text { course }\end{array}$ & $\begin{array}{l}\text { Percentage } \\
\text { of schools } \\
\text { that } \\
\text { integrate } \\
\text { research } \\
\text { instruction } \\
\text { into 1L } \\
\text { LRW } \\
\text { course }\end{array}$ & $\begin{array}{l}\text { Number } \\
\text { of schools } \\
\text { offering } \\
\text { an } \\
\text { Advanced } \\
\text { Research } \\
\text { course }\end{array}$ & $\begin{array}{l}\text { Percentage } \\
\text { of schools } \\
\text { offering an } \\
\text { Advanced } \\
\text { Research } \\
\text { course }\end{array}$ & $\begin{array}{l}\text { Number } \\
\text { of schools } \\
\text { requiring } \\
\text { an } \\
\text { Advanced } \\
\text { Research } \\
\text { course } \\
\text { of schools } \\
\text { requiring } \\
\text { an } \\
\text { Advanced } \\
\text { Research } \\
\text { course }\end{array}$ \\
\hline $2003-04^{165}$ & 176 & 141 & $80.1 \%$ & 35 & $19.8 \%$ & 6 & $3.4 \%$ \\
\hline $2004-05^{166}$ & 178 & 142 & $79.8 \%$ & 34 & $16.6 \%$ & 9 & $5 \%$ \\
\hline $2005-06^{167}$ & 184 & 149 & $80.9 \%$ & 39 & $21.2 \%$ & 10 & $5.4 \%$ \\
\hline $2006-07^{168}$ & 196 & 149 & $76 \%$ & 36 & $18.4 \%$ & 10 & $5.1 \%$ \\
\hline $2007-08^{169}$ & 197 & 151 & $76.6 \%$ & 43 & $21.8 \%$ & 7 & $3.5 \%$ \\
\hline $2008-09^{170}$ & 166 & 139 & $83.7 \%$ & 39 & $23.5 \%$ & 8 & $4.8 \%$ \\
\hline $2009-10^{171}$ & 191 & 154 & $80.6 \%$ & 51 & $26.7 \%$ & 8 & $4.2 \%$ \\
\hline $2010-11^{172}$ & 188 & 157 & $83.5 \%$ & 59 & $31.4 \%$ & 8 & $4.2 \%$ \\
\hline $2011-12^{173}$ & 184 & 159 & $86.4 \%$ & 56 & $30.4 \%$ & 10 & $5.4 \%$ \\
\hline $2012-13^{174}$ & 190 & 163 & $85.8 \%$ & 54 & $28.4 \%$ & 12 & $6.3 \%$ \\
\hline
\end{tabular}

161. Mader \& Rosenthal, supra note 158 , at 25.

162. Aden \& Becker, supra note 42 , at 21 . From a review of the course offerings at all ABA approved law schools, it appears that $81 \%$ of schools offer some form of an advanced legal research course. Data on file with author.

163. John Mollenkamp et al., ALWD/LWI 2011 Survey Report, LEgal WriTING INST. 25, https://bit.ly/38NDMdw [https://perma.cc/BPM6-AF7G] (last visited Dec. 2, 2019).

164. The survey asked respondents to indicate whether the Advanced Research Course counted toward or was required to satisfy the advanced writing requirement.

165. Gerdy \& Berres-Paul, supra note 155.

166. Kristin Gerdy et al., ALWD/LWI 2005 Survey Results, Legal Writing INST., https://bit.ly/2AVCn8q [https://perma.cc/EK3B-9ASE] (last visited Dec. 2, 2019).

167. Phillip Frost et al., ALWD/LWI 2006 Survey Results, Legal Writing INST., https://bit.ly/3fo1FuR [https://perma.cc/X43Q-CXGY] (last visited Dec. 2, 2019).

168. Philip Frost et al., ALWD/LWI 2007 Survey Results, Legal Writing INST., https://bit.ly/3ftNUeg [https://perma.cc/WCU7-EL25] (last visited Dec. 2, 2019). 


\begin{tabular}{|l|l|l|l|l|l|l|l|}
\hline $\begin{array}{l}\text { Survey } \\
\text { year }\end{array}$ & $\begin{array}{l}\text { Number of } \\
\text { schools } \\
\text { responding }\end{array}$ & $\begin{array}{l}\text { Number } \\
\text { of schools } \\
\text { that } \\
\text { integrate } \\
\text { research } \\
\text { instruction } \\
\text { into 1L } \\
\text { LRW } \\
\text { course }\end{array}$ & $\begin{array}{l}\text { Percentage } \\
\text { of schools } \\
\text { that } \\
\text { integrate } \\
\text { research } \\
\text { instruction } \\
\text { into 1L } \\
\text { LRW } \\
\text { course }\end{array}$ & $\begin{array}{l}\text { Number } \\
\text { of schools } \\
\text { offering } \\
\text { an } \\
\text { Advanced } \\
\text { Research } \\
\text { course }\end{array}$ & $\begin{array}{l}\text { Percentage } \\
\text { of schools } \\
\text { offering an } \\
\text { Advanced } \\
\text { Research } \\
\text { course }\end{array}$ & $\begin{array}{l}\text { Number } \\
\text { of schools } \\
\text { requiring } \\
\text { an } \\
\text { Advanced } \\
\text { Research } \\
\text { course } \\
\text { of schools } \\
\text { requiring } \\
\text { Advanced } \\
\text { Research } \\
\text { course }\end{array}$ \\
\hline $2013-14^{175}$ & 178 & 154 & $86.5 \%$ & 50 & $28 \%$ & 11 & 11 \\
\hline $2014-15^{176}$ & 194 & 165 & $85 \%$ & 60 & $30.9 \%$ & 11 & $6.2 \%$ \\
\hline $2016-17^{177}$ & 182 & 135 & $74.1 \%$ & n/a & n/a & 13 & $7.1 \%$ \\
\hline $2017-18^{178}$ & 182 & 144 & $79.1 \%$ & n/a & n/a & 12 & $7 \%$ \\
\hline
\end{tabular}

Thus, although there has been some movement toward at least offering more than the basic introduction to legal research capable of being taught in an integrated first-year legal research and writing course, the vast majority of law schools have yet to change their placement of research instruction. In other words, the status quo in legal research continues to treat a necessary lawyering skill—a skill recent graduates recognize as important—as the stepchild in the curriculum.

169. Philip Frost et al., ALWD/LWI 2008 Survey Results, Legal Writing InsT., https://bit.ly/2DAIhga [https://perma.cc/X2HK-6RZL] (last visited Dec. 2, 2019).

170. John Mollenkamp et al., ALWD/LWI 2009 Survey Results, LEgal WRITING INST., https://bit.ly/2Z190FJ [https://perma.cc/BN4L-22JK] (last visited Dec. 2, 2019).

171. John Mollenkamp et al., ALWD/LWI Report of the Annual Legal Writing Survey-2010, LeGAL Writing INST., https://bit.ly/2OfS6Cc [https://perma.cc/ 3FR5-EG9W] (last visited Dec. 2, 2019).

172. John Mollenkamp et al., ALWD/LWI Report of the Annual Legal Writing Survey-2011, Legal Writing INST., https://bit.ly/32bbAjJ [https://perma.cc/ FAF4-GQAV] (last visited Dec. 2, 2019).

173. George Mader et al., ALWD/LWI Report of the Annual Legal Writing Survey-2012, LEGAL WRITING INST., https://bit.ly/3ert1Pb [https://perma.cc/ 8YM9-6P99] (last visited Dec. 2, 2019).

174. George Mader et al., ALWD/LWI Report of the Annual Legal Writing Survey-2013, Legal Writing Inst., https://bit.ly/302TT31 [https://perma.cc/ U4AP-T4GR] (last visited Dec. 2, 2019).

175. George Mader et al., ALWD/LWI Report of the Annual Legal Writing Survey-2014, LEGAL WRITING INST., https://bit.ly/2OffIa2 [https://perma.cc/ 8RRB-VC5X] (last visited Dec. 2, 2019).

176. Jodi Wilson et. al., ALWD/LWI Report of the Annual Legal Writing Survey-2015, LeGAL Writing INST., https://bit.ly/313IOiN [https://perma.cc/WK5DWYVB] (last visited July 31, 2020).

177. Jodi Wilson et al., ALWD/LWI Report of the 2016-2017 Survey, LEgaL WRITING INST., https://bit.ly/2BUEObW [https://perma.cc/6P2W-CM4H] (last visited July 12, 2020).

178. Alyssa Dragnich et al., Report of the 2017-2018 Institutional Survey, LEGAL WRITING INST., https://bit.ly/30W7jj7 [https://perma.cc/QDX6-NS2K] (last visited Dec. 2, 2019). 
Law schools continue to devote too few resources and credit hours to teaching this critical skill. ${ }^{179}$ Legal research continues to be taught in courses that have a broad range of learning goals at the overwhelming majority of law schools. ${ }^{180}$ In their most recent legal writing survey, the Association of Legal Writing Directors and the Legal Writing Institute reported that fewer than 10 percent of law schools require an advanced legal research course ${ }^{181}$ and 68.6 percent of schools offer introductory research instruction in a course that includes other lawyering skills. ${ }^{182}$

Because of the broad range of goals and skills taught by these courses, students have only a few research assignments and cannot be expected to obtain much competency in these courses. ${ }^{183}$ "Legal research is rarely discussed or called on to be put into practice during other law school courses, despite being a critical skill." ${ }^{184}$ Moreover, the introductions to legal research students receive in their first-year course are just that: introductions. ${ }^{185}$

179. Glesner Fines, supra note 75, at $174-75$ ("When one focuses specifically on legal research skills . . . it is easy to conclude that ' $[\mathrm{t}]$ he curriculum often does not recognize legal research as a necessary, intellectual skill.'” While every law school does require students to have legal research instruction, at the overwhelming majority of law schools, research is taught as part of the legal writing program, with the number of schools reporting integrated programs growing each year between 2000 and the present. Research instruction is only a small part of the broad range of learning goals targeted by these first-year courses. In any given first year writing course that incorporates legal research, students will likely also be taught basics of the structure of the legal authority; pre-writing analytical processes; organization, grammar, usage, and style in writing; appropriate format and tone for a variety of legal documents; citation format; professionalism; and a variety of oral communication skills. Bibliographic instruction in sources of legal research may be separated out for special "workshops" outside the regular structure of the coursework. Most courses will include research exercises separate from writing exercises as well as 'open research' writing assignments. Needless to say, with all the learning goals jostling for priority in these courses, students cannot be expected to have acquired much competency in legal research in the first year.").

180. Tung, supra note 114, at 174-75.

181. Of the 182 schools surveyed, only $7.1 \%$ reported a required advanced research course. See Wilson \& Dragnich, supra note 157, at 21. This is an imperfect measure. The survey tallies only schools that require an advanced legal research course that satisfies the school's advanced writing requirement. It could be possible, of course, to require an advanced legal research course that did not satisfy the advanced legal writing requirement. That information, however, is not captured by the survey.

182. Id. at 26.

183. Glesner Fines, supra note 75, at 174-75.

184. Alyson M. Drake, The Need for Experiential Legal Research Education, 108 L. LiBr. J. 511, 518 (2016).

185. See id. at 519. 
Legal research instruction comprises but a small amount of time in the legal research and writing courses. ${ }^{186}$ At the majority of schools, legal research instruction is equivalent to one credit hour. ${ }^{187}$ This scant amount of instruction simply is not enough time or content to allow students to learn what they need to know to become competent legal researchers. ${ }^{188}$ While the delivery method of legal sources has shifted, legal research instruction in the first year focuses on where to find information and the process to conduct legal research. ${ }^{189}$ And research instruction continues, rightfully, to be taught in conjunction with other skills. ${ }^{190}$ In other words, legal research instruction in most law schools remains exclusively part of the first-year curriculum, the "step-child in legal education." 191

\section{B. Despite This Stagnation, Legal Research is More Complex, and Students are Less Academically Prepared}

This lack of change in the placement of legal research instruction and the number of hours devoted to it does not, however, indicate that the content and focus of the instruction itself has stagnated. Nor does it indicate that those tasked with teaching legal research have not adjusted the content of legal research instruction to try to address the shifting legal research landscape.

The changes in legal research have been profound over the last 45 years. ${ }^{192}$ When one long-time legal research professor began teaching in 1975, it was a simpler time for those teaching and conducting legal research. ${ }^{193}$ Then, legal information was compiled in

186. Glesner Fines, supra note 75, at 173.

187. Dragnich, supra note 178, at 28.

188. See Tung, supra note 114, at 239.

189. Margolis \& Murray, supra note 87 , at $118-19$.

190. Bowman, supra note 30, at 513-14 ("Legal research is so integral to problem solving and to the communication of arguments, written and oral, that it is difficult to separate research from other skills, such as writing, and researching the law is a complex skill."); Osborne, supra note 69, at 407 ("Further complicating the question of how to successfully teach research is the question of how prepared today's first-year student is for law school. Analysis, research, and writing are symbiotic. You research to locate information, analyze it for fit to the specified context, and ultimately communicate the result, frequently in a written format, be it a letter, memo, brief, or e-mail.").

191. Drake, supra note 184, at 518 ("Despite the well-recognized need for legal research education, legal research courses remain the 'stepchild in legal education.' Any required legal research instruction is offered almost exclusively in the first year; rarely is there any mandated assessment of students' research skills between the first-year legal skills course and the students' graduating and stepping out into the world of practicing law."); Glesner Fines, supra note 75, at 174-75.

192. Berring, supra note 103, at 9.

193. Id. 
books, and those sources could be trusted. ${ }^{194}$ To conduct legal research, an attorney or law students would head to a library. ${ }^{195}$ She would then check various finding tools, such as a digest, a volume of Shephard's, or an annotated statutory code, to guide her to the published sources of the law. ${ }^{196}$ She would then walk to another shelf in the library, choose the correct print reporter, for instance, and read a published opinion out of a physical book. ${ }^{197}$ Moreover, there was no up-to-the-minute way to determine if a legal sources was still good law, and there was no method to get legal information quickly; publishers struggled to ship loose-leaf services, pocket parts, supplementary pamphlets, and advance sheets from coast-tocoast in a timely fashion. ${ }^{198}$ "In 1975, it was miraculous that BNA's U.S. Law Week could deliver the full text of the opinions of the Supreme Court of the United States to the west coast within 48 hours. Not only was there no Internet, there was no fax, no email, and no FedEx." 199

This relative simplicity meant that teaching legal research was a matter of teaching students how to use a few finding tools, how to use indexes creatively, and where legal information was published. $^{200}$ For much of the history of legal research education, schools taught research using the bibliographic method. How legal research was taught began to shift in the 1980s. ${ }^{201}$ Instead of teaching students about using books in the abstract, legal research began to be linked to solving problems with students learning a process approach through recursive research activities. ${ }^{202}$ As computer-assisted legal research came onto the scene, the initial iterations mirrored books, and legal research transplanted the methods for conducting book research into computer-assisted legal research

194. $I d$.

195. $I d$.

196. $I d$.

197. $I d$

198. $I d$.

199. Id. at $9-10$.

200. Margolis \& Murray, supra note 87, at 123.

201. Tung, supra note 114, at 219 ("Legal research skills courses, usually styled as "legal bibliography," became part of the standard J.D. curriculum during the first half of the twentieth century and were frequently taught by librarians. Legal writing courses emerged in the years after World War II and "mushroomed" in the early 1980s. As legal writing programs became more familiar and established within law schools, librarian-led stand-alone research courses became less common. Legal writing faculty are now considered to have primary responsibility for $1 \mathrm{~L}$ research instruction at most law schools.”); Margolis \& Murray, supra note 87 , at 123 .

202. Margolis \& Murray, supra note 87, at 123. 
platforms. ${ }^{203}$ But in the last 20 years, there has been a dramatic shift in the availability and organization of legal information. ${ }^{204}$ This shift has changed the way legal research is conducted ${ }^{205}$ and taught. ${ }^{206}$

Most schools continue to teach secondary source, case law, statutory, legislative history, and administrative law research as part of their required first-year legal research and writing course. ${ }^{207}$ But students are now taught to locate these sources using multiple platforms: books, free or low-cost resources, and Westlaw and Lexis. ${ }^{208}$ Legal research training has constantly focused on sources-"where legal information is published"-and on "how to use various finding tools and other secondary sources to find material within the various sources of primary legal authority." 209 Added to this, however, are lessons on information literacy. ${ }^{210}$ "Information literacy is the ability to identify what information is needed, understand how the information is organized, identify the best sources of information for a given need, locate those sources, evaluate the sources critically, and share that information."211

In other words, in addition to teaching various sources and how to find information, legal research instruction now includes instruction designed to give students a deeper understanding of electronic research. This instruction will enable students to transfer the skills they are currently learning to new platforms that will come as technology continues to evolve and change. ${ }^{212}$ Those tasked with teaching legal research are facing teaching novice researchers a foundational lawyering skill in an increasingly complex environment. ${ }^{213}$ The proliferation of the legal information available means that students must be taught to manage information in an "effective

203. Id.

204. Id. at 124 .

205. Id. at $123-26$.

206. See, e.g., Rowe, supra note 103, at 42-44.

207. Osborne, supra note 69, at 413.

208. Margolis \& Murray, supra note 102, at 25.

209. Margolis \& Murray, supra note 87, at 119.

210. Margolis \& Murray, supra note 102, at 27.

211. Margolis \& Murray, supra note 87, at 120 (quoting What is Information Literacy?, UnIV. OF IDAHO: INFO. Literacy PoRTal, http://www.webs.uidaho.edu /info_literacy/ [now available at https://bit.ly/33v7W4z [https://perma.cc/PST2$\mathrm{N} 5 \mathrm{H} 9 \mathrm{]}])$.

212. Id. at 119-20; Mary Nicol Bowman \& Lisa Brodoff, Cracking Student Silos: Linking Legal Writing and Clinical Learning Through Transference, 25 Clinical L. Rev. 269, 272 (2019) ("The importance of transfer has been implicit in the recent call for law schools to produce "practice-ready lawyers." ).

213. Osborne, supra note 69, at 406. 
and efficient manner[.]"214 In short, legal research tasks are more complex. ${ }^{215}$

Moreover, those tasked with teaching the new complexities of legal research are also tasked with teaching students who are less prepared for the rigors of law school than the students of old. ${ }^{216}$ As one commentator bluntly put it: "any expectations that we may still harbor that entering law students have already developed critical thinking and problem-solving skills and that these skills can be taken to a higher level in law school simply does not match reality in many cases."217

Entering law students have scant, if any, prior experience with the kind of reading, writing, and research that the law school curriculum requires. ${ }^{218}$ Modern law students no longer matriculate ready to master the law; instead, "they now need additional supports to master the fundamental learning skills critical to learning the law."219 And they are no longer prepared to spend the amount of time studying that it takes to master the law. ${ }^{220}$ Changes to both undergraduate and primary education have led to students "who go from high school to college without the critical thinking and problem-solving skills needed for higher education and who are then less likely to obtain those skills during their undergraduate education than in the past." 221 The rigor of undergraduate education has markedly decreased over the last fifty years. ${ }^{222}$

Nearly half of undergraduate students show "no improvement in critical thinking, complex reasoning, and writing skills in the first two years of college, and $36 \%$ show no progress in four years." 223 Additionally, a "markedly small percentage of college graduates excel in higher order thinking and cognitive skills-specifically $16 \%$

214. Id.

215. $I d$.

216. Bloom, supra note 51 , at 116 .

217. Karen McDonald Henning \& Julia Belian, If You Give A Mouse A Cookie: Increasing Assessments and Individualized Feedback in Law School Classes, 95 U. Det. Mercy L. Rev. 35, 40 (2017).

218. Id. at 40; Flanagan, supra note 4, at 115.

219. Flanagan, supra note 4 , at 115.

220. Id.

221. McDonald Henning \& Belian, supra note 217, at 40; Flanagan, supra note 4 , at 115 ("[C]ollege students are not gaining the "broad competencies" such as critical thinking, problem solving, and analytical skills that are necessary for post-graduate success.").

222. Flanagan, supra note 4 , at 115 .

223. Jennifer M. Cooper, Smarter Law Learning: Using Cognitive Science to Maximize Law Learning, 44 CAP. U. L. Rev. 551, 555 (2016) (citing Thomas H. Benton, A Perfect Storm in Undergraduate Education, Part I, Chron. Higher EDuc. (Feb. 20, 2011), http://bit.ly/2VW03AB [https://perma.cc/6PCE-H57R]). 
in written communication and $28 \%$ in critical thinking and problem solving-compared to undergraduate students in the 1980s who learned at twice the rate of contemporary college students." 224 Moreover, fewer students engage in the traditional liberal arts education with its focus on critical thinking, reading, and writing skills, and college students spend significantly less time on their studies than students of the past. ${ }^{225}$ Instead of spending their time reading, writing, and engaging in critical analysis, college students today focus on memorizing the right answer. ${ }^{226}$

In sum, entering law students' prior education "may actually be detrimental to their potential for success in law school by ingraining them with a determination to find 'the right answer' as opposed to embracing the problem-solving process required to 'think like a lawyer.'" 227 However, teachers of legal research still need to teach more complex concepts, in the same timeframe as before, to students who are less prepared, while still integrating legal research skills with legal writing. Under those circumstances, perhaps, it is unsurprising that even given the gallant efforts of those responsible for teaching legal research, students are graduating without the necessary legal research competencies.

\section{What Cognitive Psychology Teaches Us About LEARNING}

In addition to calling for fundamental changes to law school curriculum and examining the lack of legal research competencies in recent graduates, commentators have also begun to examine cognitive psychology 228 - understanding how the mind works and how students learn - in an effort to improve legal education. ${ }^{229}$ Indeed,

224. Id. at $555-56$.

225. McDonald Henning \& Belian, supra note 217, at 41.

226. Id.

227. Id. at 42.

228. Peter C. Brown et al., Make It Stick: The Science of Successful LEARNING 8 (2014) ("Cognitive psychology is the basic science of understanding how the mind works, conducting empirical research into how people perceive, remember, and think.").

229. Adamo Usman, supra note 51, at 357 (citing Terrill Pollman, The Sincerest Form of Flattery: Examples and Model-Based Learning in the Classroom, $64 \mathrm{~J}$. Legal Educ. 298, 300 (2014); Anthony S. Niedwiecki, Lawyers and Learning: A Metacognitive Approach to Legal Education, 13 Widener L. 33, $34-35$ (2006)); McDonald Henning \& Belian, supra note 217, at 37; Brian Sites, Learning Theory and the Law: Spaced Retrieval and the Law School Curriculum, 43 L. \& PsychoL. REv. 99, 101 (2019); Shailini Jandial George, Teaching the Smartphone Generation: How Cognitive Science Can Improve Learning in Law School, 66 ME. L. Rev. 163, 179-80 (2013); Emily Grant, Helicopter Professors, 53 Gonz. L. Rev. 1, 26 (2018); Gallacher, supra note 127, at 273; Flanagan, supra note 4, at 110-11("Law schools 
in order to answer the calls for reform, more skills education and creating practice-ready attorneys, schools must focus on creating life-long learners and graduating students who can competently perform legal research. ${ }^{230}$ Without a doubt, legal educators should consider applying cognitive science to their teaching because "it offers the best chance for students to learn and retain complex information."231 Lawyers must be lifelong learners, so law students need to understand effective learning strategies. ${ }^{232}$ As one recent article noted, "[l] egal educators can learn what is effective [from cognitive science research] and incorporate these research findings to improve law school learning." 233

At a basic level, learning is "the process by which these neurons band together, usually through repetition and effort, to form the neural pathways that reflect the underlying experience."234 Put another way, learning is a "change in human disposition or capability, which persists over a period of time, and which is not simply ascribable to processes of growth."235 Learning occurs when there is a long-term change in the memory or behavior of the learner and the change was caused by an experience in the learner's environment. ${ }^{236}$

have been thoroughly, and deservedly, criticized for failing to teach in a manner that helps students learn.").

230. Adamo Usman, supra note 51, at 359-60 ("In response to mounting criticism, law schools have been shifting their focus to producing 'practice-ready' attorneys. Practical skills education in preparing students to be practicing attorneys resides at the heart of such an educational mission. In fact, most recently, the American Bar Association ("ABA") has set forth a standard that requires law schools to make at least six credits of 'experiential' learning mandatory in the curriculum. With such a focus, legal education has moved beyond teaching to the end of the semester exam or even the bar exam but instead has shifted to a focus on long-term skill development that will aid a student in practice."); Meyer, supra note 75 , at 454; Bloom, supra note 51, at 119.

231. Meyer, supra note 75, at 454; Grant, supra note 229, at 28 (noting that "the introduction of new teaching methods can be a very good thing for the legal classroom.").

232. Jennifer M. Cooper \& Regan A. R. Gurung, Smarter Law Study Habits: An Empirical Analysis of Law Learning Strategies and Relationship with Law GPA, 62 St. Louis U. L.J. 361, 366 (2018); Bloom, supra note 51, at 118 ("Add to that the reality that the practice of law requires lifelong learning and it becomes clear that using an extensive array of strategies to teach our students how to teach themselves may be more important than teaching doctrine.").

233. Cooper, supra note 223, at 577.

234. James B. Levy, Teaching the Digital Caveman: Rethinking the Use of Classroom Technology in Law School, 19 Chap. L. Rev. 241, 255 (2016).

235. Schwartz, supra note 52, at 366.

236. Id. 
Yet, much of what we think we know about learning is wrong. ${ }^{237}$ Even worse, "much of what we've been doing as teachers . . . isn't serving us well." 238 When students experience the increased cognitive effort associated with active learning, they initially take that effort to signify poorer learning; conversely, when they passively listen to an engaging lecture, they report feeling like they learned better. ${ }^{239}$ Cognitive psychology also teaches us, however, that optimal teaching is not linear, nor should it be easy. ${ }^{240}$

Cognitive psychology "emphasize[s] the learning of intellectual skills, such as how to apply principles and use learned procedures, how to reason, and how to combine learned principles and procedures in new ways to solve complex problems." 241 If we explicitly teach students using the knowledge from cognitive psychology, we assist "students in becoming self-regulated, expert learners." 242 This method, in turn, helps our students become academically successful and sets them up to be effective life-long learners. ${ }^{243}$ Moreover, it sets the students up to achieve mastery of both the knowledge and skills they need to be competent, successful attorneys. $^{244}$

Despite the perception that students are learning more when it seems easy, "[w]hen learning feels hard, it actually sticks and lasts longer." 245 Students need to engage in active learning to change information into knowledge, to develop critical thinking skills, and to become ready to practice law. ${ }^{246}$ Students need to both forget material and make mistakes in order to learn. ${ }^{247}$ Forgetting and

237. Cooper \& Gurung, supra note 232, at 369-70.

238. Joni Larson, To Develop Critical Thinking Skills and Allow Students to Be Practice-Ready, We Must Move Well Beyond the Lecture Format, 8 Elon L. REV. 443, 459 (2016) ("While lecturing has been a staple in the law school classroom, it comes with limitations. The most important limitation is that it does not create an opportunity for students to actively engage with the content or acquire the skills they will need to practice law."); see also BROWN ET AL., supra note 228, at 9 .

239. Deslauriers et al., supra note 123, at 19251.

240. Brown ET Al., supra note 228, at 11; Daniel T. Willingham, Why Don't Students Like School 131, 142-43 (2009) (learning takes hard work and practice).

241. Schwartz, supra note 52, at 372.

242. Cooper \& Gurung, supra note 232, at 369-70.

243. See Cooper, supra note 223 , at $576-80$.

244. See Henning \& Belian, supra note 217, at 48-49; see also Bloom, supra note 51 , at $121-22$.

245. Cooper \& Gurung, supra note 232, at 369-70; Bloom, supra note 51, at 121-22; Deslauriers et al., supra note 123, at 19251; Flanagan, supra note 4, at 123.

246. Larson, supra note 238, at 460. 123.

247. Cooper \& Gurung, supra note 232, at 369-70; Flanagan, supra note 4, at 
making mistakes show knowledge gaps and create opportunities for learning. Additionally, doing the hard, slow, challenging work of learning sets students up to retain and transfer both information and skills. ${ }^{248}$ "Retention is the ability to remember the information or demonstrate the skill learned. Transfer is the ability to apply that information or execute the skill across different but related situations."249

The increased ability to retain and transfer knowledge and skills by doing the hard, slow, challenging work of learning takes place because learning is optimal when (1) it is difficult; ${ }^{250}$ (2) it allows students to create a structure they can then build on; (3) it uses spaced, varied, and interleaved practice; and (4) it teaches students how to fail successfully. ${ }^{251}$ "Retrieval and space[d], varied, interleaved practice challenge learners and create desirable difficulties. ${ }^{252}$ In turn, introducing desirable difficulties into learning creates better, longer-lasting learning "because the students have to work harder at their cognitive skills." 253

Furthermore, optimal learning requires time: "time for learning, storage, forgetting, retrieving, and consolidating information." 254 When first learning, the learner is disorganized as she takes in new information, unsure of how the information fits together. $^{255}$ This information is in the learner's working memory. ${ }^{256}$ The learner must commit the information to her long-term memory. ${ }^{257}$ The critical step for learning is moving information from working or short-term memory to long-term memory. ${ }^{258}$ Not all in-

248. Bloom, supra note 51, at 121.

249. Id. at 121-22.

250. Henning \& Belian, supra note 217 , at 48.

251. Adamo Usman, supra note 51, at 360-72; George, supra note 229, at 185 ("Five techniques showed evidence of a correlation to learning: distributing practice on tasks (spreading learning out over time rather than in a massive block or back-to-back sessions-i.e., 'cramming'); retrieval practice (testing); interleaved practice (study of one topic interleaved with study of another topic, i.e., studying contracts and torts intermittently); elaborative interrogation (students question the information while studying it) and self-explanation (students explain procedures or information to themselves or others).").

252. Cooper, supra note 223, at 571.

253. Ruth Vance \& Susan Stuart, Of Moby Dick and Tartar Sauce: The Academically Underprepared Law Student and the Curse of Overconfidence, 53 DuQ. L. REV. 133, 160 (2015).

254. Cooper, supra note 223, at 572.

255. Id.

256. Gerald F. Hess, Value of Variety: An Organizing Principle to Enhance Teaching and Learning, 3 ELON L. REV. 65, 67 (2011).

257. Henning \& Belian, supra note 217 , at $48-49$.

258. Hess, supra note 256, at 67. 
formation is transferred. ${ }^{259}$ Instead, to be transferred, the information must be meaningful and integrated with prior knowledge. ${ }^{260}$

The long-term memory is organized into schemata or mental models. ${ }^{261}$ Once stored in her long-term memory, the newlylearned information is consolidated-reorganized and connected to past experiences and knowledge that is already stored in her longterm memory. ${ }^{262}$ When the learner has to retrieve information after a lapse in time, "the act of retrieving information from longterm storage strengthens the memory and enables it to be connected to more recent learning." 263 The more effort the learner puts into the process of taking in information, consolidating it, and retrieving it, the more likely it is that the information or skills will become entrenched and that she will achieve mastery. ${ }^{264}$ In other words, "the act of retrieving information from long-term storage strengthens the memory and enables it to be connected to more recent learning. This reconsolidation is how retrieval practice makes learning more durable. ${ }^{265}$ In fact, to truly "learn" information, the brain must make connections to that material multiple times, using practice and effort. ${ }^{266}$

Retrieval is such a powerful learning tool because the act of retrieving information from memory is more difficult than rereading or simply seeing the information again-instead it generates learning. ${ }^{267}$ When learners retrieve information, they "re-store it in their memories in a different way than before." 268 Retrieval is more effective learning than the initial encoding. ${ }^{269}$ Moreover, "[t]he more difficult it is to retrieve the information, the harder the brain works to dig up that information and the greater the learning." 270

To be most effective, retrieval practice should be spaced. ${ }^{271}$ Spaced retrieval practice leads to forgetting, which leads to more difficulty recalling the information. ${ }^{272}$ And it is this forgetting that

\footnotetext{
259. Id.

260. Id.

261. Id.

262. Cooper, supra note 223, at 572.

263. Id.

264. Henning \& Belian, supra note 217 , at $48-49$.

265. Cooper, supra note 223, at 572.

266. Levy, supra note 234, at 258; Flanagan, supra note 4, at 121-22.

267. Cooper, supra note 223, at 562; Flanagan, supra note 4, at 123.

268. Cooper, supra note 223, at 562; Flanagan, supra note 4, at 123.

269. Cooper, supra note 223, at 562; Flanagan, supra note 4, at 123.

270. Cooper, supra note 223, at 562; Flanagan, supra note 4, at 123.

271. Flanagan, supra note 4, at 123.

272. Id.
} 
is such an essential component of learning. ${ }^{273}$ "Learning that is retrieved multiple times, over long periods of time, is not stored with specific context because the context changes with each retrieval, creating greater memory traces and a greater likelihood of retrieval in the future." 274

Additionally, while blocked retrieval can be effective, it is not optimal. $^{275}$ If a student retrieves information from only one subject, once she knows the answer or strategy, the hard part of learning is over. ${ }^{276} \mathrm{~A}$ better method of learning is interleaving. ${ }^{277}$ Interleaving is the spaced practice of retrieving information from various subjects. ${ }^{278}$ Thus, spaced, varied, and interleaved retrieval is one of "the most powerful, if not the most powerful, learning tool available." 279

While spaced, varied, and interleaved retrieval requires more effort than retrieving information from a single subject, it creates better learning. ${ }^{280}$ Spaced, varied, and interleaved retrieval practice helps learners "discriminate between different types of problems and select the correct strategy." 281 This form of practice also requires the learner to make "quick decisions and shift strategies." 282 The learner's brain must continuously focus on retrieving the correct solution from various encoded information, which in turn improves her ability to learn the critical features of skills and concepts, and enables her to select and execute a better response. ${ }^{283}$

The application of cognitive psychology to the law school curriculum could be profound. If this knowledge were applied to learning across the curriculum, it would have significant, long-term benefits for students. ${ }^{284}$ "Research has found that the best lag time between study sessions for 350 days of retention is a 21 day interval[,]" and research suggests that the longer you want retention to last, the longer you need to space the retrieval practice. ${ }^{285}$ Cognitive psychology teaches us that when spaced, interleaved retrieval

273. Id.

274. Id.

275. Steve C. Pan, The Interleaving Effect: Mixing It Up Boosts Learning, SCIENTIFIC Am. (Aug. 4, 2015), https://bit.ly/3gHvfLZ [https://perma.cc/P7QT-63U5].

276. Id.

277. Cooper, supra note 223, at 570.

278. Id.; Flanagan, supra note 4, at 124.

279. Sites, supra note 229 , at 113.

280. Cooper, supra note 223, at 570.

281. Id.

282. Id.

283. Pan, supra note 275.

284. Flanagan, supra note 4, at 124.

285. Id. 
practice is expanded across months and years rather than limited to semesters or courses, students achieve transfer. ${ }^{286}$ By applying spaced, interleaved retrieval practice across the three years of law school,

students [would] reap the benefits of durable, long-term learning ... that is more readily transferred to new, novel problems .... [S]tudents can practice transfer of knowledge as the problems become more complex in later courses. Transfer is an essential part of successful learning and critical to success in later practice. ${ }^{287}$

The goal of legal education is for students to retain skills and knowledge for a lifetime, and for students to be able to transfer their skills and knowledge to new contexts and problems. ${ }^{288} \mathrm{In}$ deed, transfer of knowledge is the essence of what attorneys dodraw upon a set of core lawyering skills when faced with diverse facts and legal disciplines to solve a new problem. ${ }^{289}$

\section{Including Legal Research Across the Curriculum Would Create Competent Legal Researchers}

As legal education needs to foster long-term learning and transfer of skills, the use of principles from cognitive psychologyspaced, varied, and interleaved practice- to build a better curriculum should be the goal of every law school. ${ }^{290}$ Thus, to foster these learning goals, as well as to ensure that students are competent legal researchers, legal research instruction needs to stop being the stepchild of legal education and become a part of every course.

The original call for legal research across the curriculum included a modest proposal. During the first year, the majority of research instruction would remain in the Legal Research and Writing course, but the other professors could enhance these lessons by incorporating discussions of citation found in the cases in casebooks to identify mandatory or persuasive authority; discussing when the reading assignments draw on secondary sources, and how courts and legislatures use secondary sources; or including short research exercises to cover topics not covered by the casebook or help students analyze hypothetical factual scenarios. ${ }^{291}$ During the remaining years, the call proposed requiring an advanced legal research

286. $I d$.

287. $I d$.

288. $I d$.

289. Kowalski, supra note 54, at 52.

290. See Flanagan, supra note 4, at 123-24.

291. Bowman, supra note 30 , at 557-58. 
course; having professors who teach in subjects with unique resources like International Law and Tax Law incorporate instruction on using those resources and include research exercises; and requiring students who complete a concentration to complete a one-credit legal research course focusing on materials related to that concentration. $^{292}$

Since the original call, proposals to include more research instruction across the curriculum have included imbedding law librarians within law clinics to provide individualized guidance as students work on real cases, ${ }^{293}$ designating advanced legal research courses as experiential courses, ${ }^{294}$ or including more legal research instruction in the required upper-division legal writing courses and other writing intensive courses. ${ }^{295}$ Beyond the calls for specific inclusion of research skills across the curriculum, bolder calls for reform have included using the problem-based method of instruction for the entire curriculum in which students would explore the law in the way lawyers actually work and have to research the law $^{296}$ or devoting the entire second and third years of law school to service and experiential learning. ${ }^{297}$

While each of these proposals is laudable, the original call would be only a beginning step toward truly designing a curriculum based on spaced, varied, and interleaved retrieval practice in order to graduate competent researchers. A competent researcher needs five core skills: he must (1) possess "foundational knowledge of the legal system and legal information sources"; (2) gather "information through effective and efficient research strategies"; (3) "evaluate[] information" critically; (4) apply "information effectively to solve a specific issue of need"; and (5) distinguish "between ethical and unethical uses of information, and understand[ ] the legal issues associated with the discovery, use, or application of information." 298 Discussions of case citations to identify mandatory or persuasive authority and how various governmental bodies use secondary sources would certainly help students gain a knowledge of the legal system, and those discussions might help them critically evaluate information or begin to identify how to apply information to solve a specific problem. The original call would not, however,

292. Id. at 558-59.

293. Nancy Vettorello, Resurrecting (and Modernizing) the Research Treasure Hunt, 109 L. LiBR. J. 205, 212 (2017).

294. Drake, supra note 184, at 533.

295. Glesner Fines, supra note 75, at 176.

296. Gallacher, supra note 127, at 277.

297. Flanagan, supra note 4, at 131-38.

298. Am. Ass'n of Law Libraries, supra note 109, at 1. 
help them to understand legal information sources or how to use them, to find the information that would solve a client's problem, or to understand the ethical uses of information.

Moreover, including some instruction on the sources of legal information in courses whose topics have specialized resources, such as International Law or Tax Law, would build only limited practice into the curriculum. And students who did not take such specialized courses would not have the benefit of any practice in conducting research. Likewise, the proposals to imbed law librarians in clinics or to designate advanced research courses as experiential courses, would face the same limitation: students who do not take such courses would not have the benefit of additional practice with legal research.

The original proposal required all students to take an advanced research course, but even a perfectly designed course could not provide enough spaced, varied, and interleaved practice to create the optimal conditions for long-term retention and transfer as it is limited by a semester or year-long course structure. As such, the original call does not go far enough to ensure that students receive the benefit of a research curriculum built around the principles of cognitive psychology.

This same limitation applies to the call for more research instruction in advanced writing courses. Even if such a course were designed to touch on all the legal research competencies and provide spaced, varied, and interleaved retrieval practice in all those competencies, it would still be limited to a semester. Thus, this call does not go far enough to ensure that all students receive the benefits of the research curriculum.

The bolder calls could produce competent attorneys by giving students the opportunity for spaced, varied, and interleaved practice of all the research competencies. As each of the calls noted itself, however, such drastic changes to school's curriculums would be difficult and could take years. ${ }^{299}$ In the meantime, schools would be left trying to achieve research competencies for their students in a scant one-credit-hour of time during the first year.

Instead, schools should adopt an approach to research across the curriculum that goes beyond the original call and includes spaced, varied, and interleaved practice of the various research skills in most, if not all, courses. Each course could include discussions of how legal information is used within the legal system, as the original call noted. Even the simple discussions of citations within

299. Gallacher, supra note 127, at 269; Flanagan supra note 4, at 105. 
the cases students are already assigned would give students an opportunity to retrieve and use their knowledge of the legal system in a spaced and varied setting.

Better, though, would be changes in the delivery method of doctrinal content. For instance, all professors could include research exercises that allow students to gather and evaluate information in various contexts or exercises that allow them to apply their research results. For instance, before beginning a new topic in a course, professors could ask the students to contextualize the upcoming discussion by researching the topic in a secondary source. Once students understand the basic rule, they could research exceptions to the rule in a specific jurisdiction. Perhaps there is a doctrine that exists in a jurisdiction, but it is not covered in the casebook? Students could research that doctrine and use their research to solve a hypothetical client's problem. These types of exercises would provide the spaced, varied, and interleaved practice at conducting legal research that students need to become competent legal researchers. And these types of exercises would allow the professors to retain ownership over the content of their courses.

Likewise, the questions that appear after cases in many casebooks are ripe for research problems. Rather than having students simply analyze those questions based on their knowledge from the casebook, students could move a step beyond this and research the issue presented. For more cutting-edge issues or issues related to discovery and professional ethics, students could access briefs filed in a recent case. This instruction method would allow students to evaluate how attorneys are using information or to understand issues related to the ethical use of information.

While some faculty members may feel skeptical about including skills instruction in a course, it can no longer be argued that law schools can produce graduates without legal research competency. Legal research is a core skill all attorneys must possess. Moreover, law professors possess the core skill of legal research and the core skill of unpacking legal information, even if they feel they lack the ability to unpack the information. As such, each professor should be able to review the legal research instruction students have already received and the skills the students would need to complete a research exercise, and then determine what additional information or instruction the students would need. ${ }^{300}$ Thus, the content of legal research instruction belongs to all law professors.

300. There are also many resources related to instructional design and research exercise design that professors could consult, in addition to drawing on the expertise of law librarians and the legal research and writing professors. 
Next, including legal research exercises would not result in the exclusion of doctrinal content from a course. Instead, including opportunities for students to practice legal research is simply a different method of delivering content. As opposed to using passive learning, such as reading cases and listening to a Socratic dialogue, including research activities is more likely to ensure that students learn the doctrinal content in addition to helping them reach competency in legal research. ${ }^{301}$ Thus, while the method of instruction for certain portions of a class would change in order to include research across the curriculum, students would still learn the content.

Finally, as with any curricular change, including research activities in most courses would take administrative and faculty commitment. As with any change in delivery method, each professor must take the time to learn methods for instruction and assessment, and then must evaluate the success of such efforts. And, while change can be difficult, changing the method of instruction for some content in courses to include a research component would have little long-term cost.

\section{CONCLUSION}

While calls for law schools to do better are nothing new, law schools can no longer ignore the critique that law students are graduating without necessary legal research competencies. The ABA, law students, and employers are demanding that law schools do better when teaching legal research. Academic critics are demanding that law professors begin to apply the lessons from the science of learning to improve student outcomes. The practice of law is changing.

Adding research discussion, lessons, or activities to courses across the curriculum would have little cost in terms of finances, minimal costs in terms of faculty time, and would not necessitate jettisoning doctrinal content from any course. Instead, this simple change in the delivery method of content would lead to better outcomes for students. The time for changing the edges of law school curriculums or for adding more mandatory or even optional courses has passed. Law schools can apply the knowledge that spaced, varied, and interleaved practice produces better learning and transfer to their curriculums.

301. "Often curricular improvement entails not adding new courses, but rather making relatively minor modifications in existing courses." Bahls, supra note 59 , at 393 . 